\title{
Closing the Gaps: An Update on Indicators of Inequality for Māori and Pacific People
}

\author{
LISA MARRIOTT AND NAZILA ALINAGHI
}

\begin{abstract}
This article updates and expands an earlier study investigating the gaps in inequality indicators between different ethnic groups in Aotearoa New Zealand (NZ). The present study updates the same inequality indicators across categories of health, knowledge and skills, employment, standard of living, and cultural identity, using more recent data. It is also extended to incorporate the third-largest ethnic group in NZ, Asian people. This ethnic group is often excluded from inequality discussions, as Asian people are typically believed to outperform, or at least be on par with, the European ethnic group.
\end{abstract}

In contrast to the earlier study, the findings in the current study show improvements in most indicators. However, Europeans continue to outperform Māori and Pacific people in all but one indicator. We find support for the suggestion that the Asian ethnic group experiences inequality less than Māori or Pacific people.

\section{Introduction}

The focus of this study is inequality. Inequality, and particularly inequality of income and wealth, has become a prominent topic in global public discourse. ${ }^{1}$ This study incorporates a range of inequality measures, including economic indicators (such as earnings) and social indicators (such as health). In particular, 19 inequality indicators, across two time periods, for the four largest ethnic groups in Aotearoa New Zealand (NZ) are examined.

The primary aim of the research is to report on whether inequality in outcomes in each of these indicators is improving or worsening for each ethnic group. We also report on the gap between Europeans and the three other ethnic groups, to highlight whether the gaps are increasing or decreasing.

This is a replica study. In the earlier study, the gaps across 21 social indicators over an approximately 10-year period (2003-2013) were examined. ${ }^{2}$ The present study reports on the differences among ethnic groups on a range of inequality measures. We examine the same indicators, but with two exceptions. In this article, we exclude the social connectedness indicator of households that have internet access. The primary reason for this exclusion is because mobile technology that is internet enabled has the potential to distort this analysis. We also exclude the household crowding indicator, as the 2018 census data remains quarantined due mainly to the further process undertaken by Statistics New Zealand on the data quality, at the time of writing. ${ }^{3}$ We make a further change to the previous study, which is to include the Asian ethnic group, in order to capture different outcomes across the four largest ethnic groups

Journal of New Zealand Studies NS32 (2021), 2-39 - https://doi.org/10.26686/jnzs.iNS32.6863 
in NZ: Europeans (70.2 percent), Māori (16.5 percent), Pacific people (8.1 percent) and Asian people (15.1 percent). ${ }^{4}$

The genesis of the original project was a Ministry of Social Development report titled Social Indicators for the Pacific and Māori Populations (2003) and a follow up report titled Reducing Inequalities Indicators for Māori and Pacific Peoples (2004). ${ }^{5}$ These publications reported on a range of indicators of inequality across the dimensions of health, knowledge and skills, paid work, economic standard of living, cultural identity, safety, and social connectedness. Of the 27 indicators in the 2003 report, six showed improvements for Pacific people and 13 showed improvements for Māori populations. The remainder produced no result, as information was not available, or no clear trend was evident. The primary element of interest from the 2003 and 2004 reports was that for Māori populations, none of the indicators showed worsening trends, while one showed a worsening trend for Pacific people. However, the previous study reported different trends: between European and Māori, 9 of the 21 indicators showed improvements in the form of decreasing gaps, although not all the improvements were significant. Of the remaining indicators, 11 showed increasing gaps and one remained unchanged. Between European and Pacific people, 6 of the 17 available indicators showed an improvement in the form of closing gaps, 10 showed increasing gaps, and one remained unchanged. ${ }^{6}$ Thus, the majority of indicators showed a trend that suggested increasing inequality between Europeans and Māori, and Europeans and Pacific people.

The format of this article is as follows. First, we provide a brief background on inequality in general and inequality in NZ specifically. Then, we describe the methods and data used in the study. The following sections report on the indicators of inequality, across the subsections of health, knowledge and skills, paid work, economic standard of living and cultural identity. We conclude with an analysis of our findings.

\section{Background}

Inequality is rather a broad notion. It can incorporate different forms, including but not limited to income, wealth or economic inequalities. As noted in the introduction, various measures of social and economic inequality are examined here. Empirical evidence has shown that income inequality is linked to lower well-being. For example, those with lower incomes tend to have poorer outcomes across many social measures including health outcomes, educational performance and general well-being. ${ }^{7}$ This is likely to embed inequality of opportunity. ${ }^{8}$ Those with more education are more likely to have higher incomes, more likely to be healthy and more likely to be employed. ${ }^{9}$

Inequality-related issues have been the subject of extensive research and debate in NZ, as they have been in many other countries. Most would agree that a high degree of inequality is undesirable, but action to reduce inequality has achieved limited success. ${ }^{10}$ The extent of wealth inequality is evident in the most recent household net worth figures produced by Statistics New Zealand. Median net worth in NZ is $\$ 138,000$ for Europeans, $\$ 29,000$ for Māori, $\$ 15,000$ for Pacific people, and \$46,000 for Asian people. ${ }^{11}$ This means that, on average, a European person

Journal of New Zealand Studies NS32 (2021), 2-39 - https://doi.org/10.26686/jnzs.iNS32.6863 
has 4.8 times as much net worth as a Māori person, 9.2 times as much net worth as Pacific people and 3 times as much net worth as Asian people. While this is a measure of wealth - that is, a static measure - wealth is an important indicator of inequality as it is well established that wealth generates wealth. Authors such as Piketty have shown how the accumulation of private capital leads to concentration of wealth in the hands of the few. ${ }^{12}$

Changes of wealth holdings in New Zealand can be seen in the Household Economic Survey (HES) data, which shows that in the three-year period from 2015 to 2018, median household net worth barely changed for the two lowest quintiles. Quintile 1 had a median net worth of $\$ 8,000$ in 2015 and $\$ 9,000$ in 2018 (a 13 percent increase); quintile 2 had a median net worth of $\$ 97,000$ in both 2015 and 2018. Quintile 3 increased 18 percent from $\$ 289,000$ to $\$ 340,000$. Quintile 4 increased 26 percent from $\$ 561,000$ to $\$ 709,000$. Quintile 5 increased 29 percent from $\$ 1,356,000$ to $\$ 1,750,000 .{ }^{13}$ To put this into perspective, the $\$ 394,000$ increase in net worth of the richest 20 percent (households in quintile 5) is 394 times the increase of the least wealthy 20 percent (households in quintile 1), 7.7 times the increase of quintile 3, and 2.7 times the increase of quintile 4 . Both relative and absolute differences are valid for discussion here. In the case of quintile one, the 13 percent increase may be viewed as significant, despite only being $\$ 1,000$. While this only shows wealth changes over a three-year period, which may be too short to draw any conclusions, the high level of wealth inequality is visible in both surveys.

In 2018, the top 20 percent of households, as measured by net worth, owned 70 percent of net assets (assets less liabilities) in NZ. This should be compared with 69 percent reported for 2015. It is worth noting that half of all households in NZ hold 94 percent of NZ's net worth. ${ }^{14}$ Research from Oxfam in January 2019 reported that the two richest people in NZ added \$1.1 billion to their wealth in 2017-2018. ${ }^{15}$ The changes over this period are shown in Figure 1. A significant part of the increase in household wealth during this period resulted from increases in property prices. However, the percentage of households who are homeowners has been declining for many years, now estimated at 62 percent in NZ. ${ }^{16}$

Journal of New Zealand Studies NS32 (2021), 2-39 - https://doi.org/10.26686/jnzs.iNS32.6863 


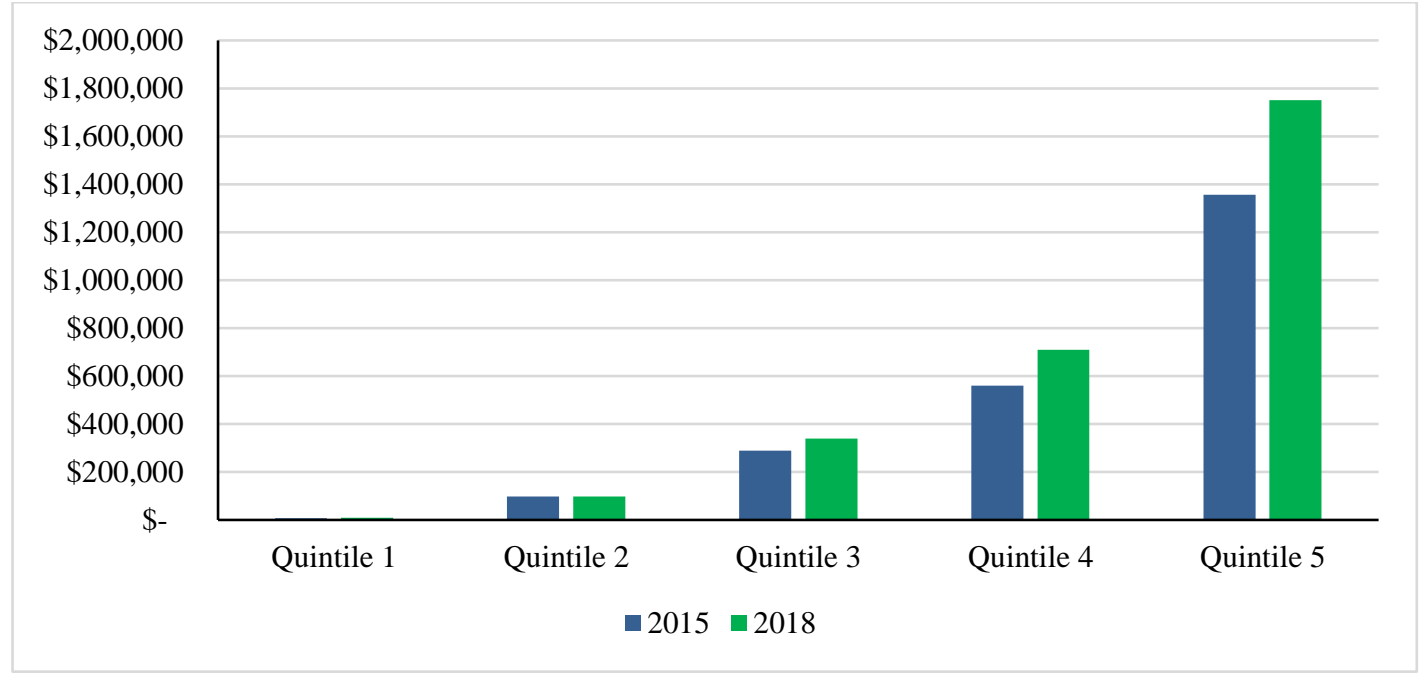

Figure 1. Median Net Worth by Household Net Worth Quintile (June 2015 and June 2018) ${ }^{17}$

The reasons why the increasing gap between those who have the most and those who have the least is undesirable is because it "erodes trust, fuels crime, makes us unhappy, negates economic growth and robs opportunity from the poorest-including shortening their lives." 18 Inequality results in a lack of social cohesion, reduced social mobility and poor health outcomes. ${ }^{19}$ It also drags down gross domestic product growth, and prevents people from realising their human capital potential. ${ }^{20}$

From the mid-1980s to the mid-2000s, income inequality has increased in New Zealand ${ }^{21}$ New Zealand is not the only country where income inequality is rising. The OECD recently reported that income inequality in OECD countries is at its highest level over the past 50 years. It argues that the benefits of growth have not been evenly distributed, and high levels of income inequality have increased. Factors driving inequality globally include globalisation, skillbiased technology change and changes in countries' policy approaches. ${ }^{22}$

The issues associated with inequality are wide ranging and connected across different types of inequality. As noted by Boston and Rashbrooke, "large income disparities pose serious economic and political risks, undermine social cohesion and raise acute ethical challenges." 23 Where people have different levels of income, they will have different opportunities, such as access to good healthcare and quality education. ${ }^{24}$ These opportunities impact on social mobility and future opportunities, thereby entrenching existing inequalities for some. Moreover, wealth inequalities are difficult to address. As noted by Piketty, "inherited wealth comes close to being as decisive at the beginning of the twenty-first century as it was in the age of Balzac's Pére Goriot... the main force in favor of greater equality has been the diffusion of knowledge and skills." 25 Thus, it is important to look across a range of inequalities in order to gain a holistic view of how different ethnicities are faring in Aotearoa New Zealand.

Journal of New Zealand Studies NS32 (2021), 2-39 - https://doi.org/10.26686/jnzs.iNS32.6863 


\section{Methodology}

This study uses the same methodology as described in the earlier article in 2015. That is, it compares inequality indicators across major ethnic groups in NZ. However, instead of comparing data over the 10-year period from 2003/2004 to approximately 2013, we have updated the data using the most recent New Zealand census data, 2018, along with data collected from other sources within approximately the same period. ${ }^{26}$ This allows us to provide an update on the direction of movement for each of the indicators.

It is worth emphasising that there are some significant data limitations. In some cases, data is not regularly reported, or it is not delivered as scheduled. For example, suicide reporting is typically some years after the reporting period, as it is necessary to correctly establish causes of death. In these cases, we use the most up-to-date data available. The health indicators are those most impacted by irregular reporting. We continue to report these measures as they provide an indication of trends. Health indicators are also less likely to be impacted by external shocks, such as recessions, which some of the economic indicators suffer from.

The following section outlines the data and statistical methods used to assess the indicators that we outline in the subsequent sections.

\section{Data}

This study investigates the differences across inequality indicators between the four largest ethnic groups in NZ: European, Māori, Asian, and Pacific people. Ethnicity is "a measure of cultural affiliation. It is not a measure of race, ancestry, nationality, or citizenship." ${ }^{27}$ Guidance on ethnicity provided by Statistics New Zealand observes that an ethnic group consists of people who have some or all of the following characteristics:

- A common proper name;

- One or more elements of common culture, such as religion or customs;

- Unique community of interests, feelings and actions;

- A shared sense of common origins or ancestry; and

- A common geographic origin. ${ }^{28}$

Individuals can self-identify with a particular ethnic group. Therefore, it is possible that a given individual belongs to more than one ethnic group.

The prior article focused on inequality differences between European and Māori, and European and Pacific people, but did not include Asian people. However, the present study includes those with Asian ethnicity. We include this group in the current study, as it is the third most common ethnic group in NZ, representing 15.1 percent of the NZ population according to the 2018 census. Of the four primary ethnic groups, the Asian group is increasing at the fastest pace, with an average annual increase of 8.4 percent in the period from 2013 to $2018 .{ }^{29}$ Asian people are often considered to be proportionately over-represented in positive indicators. Thus, 
including Asian people in this study allows us to assess this hypothesis across a range of indicators.

Following the approach adopted in the 2015 study, we provide data for each of the indicators in a table with two time periods. Each table shows the absolute and relative change over the two time periods shown, as well as the gaps between the European population, Māori, Pacific people and Asian people over the specified periods. ${ }^{30}$ A synopsis of the findings is included in Appendix 1.

\section{Statistical Methods}

Data for this study come from a variety of public sources and institutions, including 2018 Census data collected by Statistics New Zealand, and data collected by the Ministries of Health, Education and Social Development. Some data reports on complete counts of individuals or a census of individuals. In such cases, the figures have been used as percentages without error and no statistical analysis has been done.

Other estimates of percentages come from survey data. In these cases, we have tried to determine the sampling error in the percentages so that we can conduct the appropriate test to determine if there is enough evidence for a difference between ethnic groups. This has not always been possible but, when it has, the relevant statistics and their significance have been presented.

We have tried to use the same dataset across the two time periods. However, where this has not been possible, or where the original time period has changed, we have noted this.

We acknowledge that our approach does not follow the same individuals and/or households over time. Instead, it focuses on cross-sectional comparisons using aggregate data. As suggested by some studies, the cross-sectional comparisons can result in misleading conclusions because they necessarily ignore how each individual's income moves relative to others, over time. ${ }^{31}$ However, the main aim of this study is to examine inequality at a specific time across different ethnic groups.

\section{Indicators of Inequality}

This section is comprised of five subsections, each of which provides an update on the same indicator reported in the prior study. The measures are from the following categories: health; knowledge and skills; paid work; economic standard of living; and cultural identity.

\section{Health}

A number of studies have reported on health inequalities in NZ. Specific examples of health inequalities include the following: Māori and Pacific people are strongly associated with poorer survival from a range of common cancers, ${ }^{32}$ Māori infants have rates of sudden unexpected death in infancy that are more than six times the rate of non-Māori infants, ${ }^{33}$ and Māori infants 
are nearly three times more likely to be hospitalised with bronchiolitis than non-Māori infants. ${ }^{34}$

There are much higher rates of premature death and serious chronic disease for Māori and Pacific people living in NZ. ${ }^{35}$ Māori adult mortality is double that of non-Māori. There are multiple known factors that contribute to these health inequalities, including interpersonal and institutional racism; ${ }^{36}$ changing economic inequalities and changing health inequalities between ethnic groups; ${ }^{37}$ and environmental factors, such as significantly higher rates of tobacco consumption among Māori and Pacific people.

The following five subsections report on the same five measures of health as the original study: life expectancy at birth; prevalence of cigarette smoking; obesity; suicide rates; and infant mortality.

\section{Life Expectancy at Birth}

Life expectancy provides a readily understood means of monitoring ethnic inequalities in health. ${ }^{38}$ Some of the health indicators that are discussed in subsections below impact on life expectancy, such as obesity and tobacco usage.

Table 1 shows life expectancy for Māori, non-Māori, and Pasifika males and females. This data is not available for other ethnic groups. At the time of writing in December 2020, the most recent life expectancy figures available are for the period 2012-2014, as this data is derived every five years. ${ }^{39}$ While this does not allow us to comment with any depth on the trend, we retain the indicator in this article as it does show a continuation of the finding in the prior study, which showed a general improvement for all groups, and a closing of the gap in life expectancy between Māori and non-Māori. We also include Pacific people in this indicator, unlike our previous study, when this data was not available. While we cannot report on the overall trend of life expectancy for Pacific people, including this ethnic group will allow us to start tracking the trend for future reference.

Table 1. Life Expectancy at Birth ${ }^{40}$

\begin{tabular}{|l|l|l|l|l|}
\hline & $\mathbf{2 0 1 0 - 2 0 1 2}$ & $\mathbf{2 0 1 2 - 2 0 1 4}$ & $\begin{array}{l}\text { Absolute } \\
\text { Change* }\end{array}$ & $\begin{array}{l}\text { Relative } \\
\text { Change** }\end{array}$ \\
\hline Non-Māori (male) & 80.2 years & 80.3 years & +0.1 years & $0.1 \%$ \\
\hline Non-Māori (female) & 83.7 years & 83.9 years & +0.2 years & $0.2 \%$ \\
\hline Māori (male) & 72.8 years & 73 years & +0.2 years & $0.3 \%$ \\
\hline Māori (female) & 76.5 years & 77.1 years & +0.6 years & $0.8 \%$ \\
\hline Pacific people (male) & Not reported & 74.5 years & N/A & N/A \\
\hline Pacific people (female) & Not reported & 78.7 years & N/A & N/A \\
\hline $\begin{array}{l}\text { Gap (non-Māori males minus } \\
\text { Māori males) }\end{array}$ & 7.4 years & 7.3 years & -0.1 years & $-1.4 \%$ \\
\hline
\end{tabular}

Journal of New Zealand Studies NS32 (2021), 2-39 - https://doi.org/10.26686/jnzs.iNS32.6863 


\begin{tabular}{|l|l|l|l|l|}
\hline $\begin{array}{l}\text { Gap (non-Māori females } \\
\text { minus Māori females) }\end{array}$ & 7.2 years & 6.8 years & -0.4 years & $-5.6 \%$ \\
\hline $\begin{array}{l}\text { Gap (non-Māori males minus } \\
\text { Pacific males) }\end{array}$ & N/A & 5.8 years & N/A & N/A \\
\hline $\begin{array}{l}\text { Gap (non-Māori females } \\
\text { minus Pacific females) }\end{array}$ & N/A & 5.2 years & N/A & N/A \\
\hline
\end{tabular}

$*$ Absolute Change $=$ Value of indicator in period $2-$ Value of indicator in period 1

$* *$ Relative Change $=\frac{\text { Value of indicator in period } 2-\text { Value of indicator in period } 1}{\text { Value of indicator in period } 1} \times 100 \%$

Table 1 shows the continued trend of a reducing gap between Māori and non-Māori. However, the improvement, particularly for Māori males, is slow. Over the two years investigated, the gap between Māori males and non-Māori males has closed by 0.1 of a year. While this result is a positive outcome, it suggests that if this rate continues it will take 146 years to eliminate the gap. However, it is worth noting that the period considered here might be relatively short for any generalization. The gap between non-Māori and Māori females is slightly less than males at 6.8 years, compared to 7.3 years. The gap between non-Māori and Māori females has decreased by 5.6 percent. At current rates of improvement, it will take 34 years to eliminate this gap.

\section{Cigarette Smoking}

Smoking prevalence is higher among Māori and Pacific people (compared to their European counterparts) and among those in low socioeconomic groups. Consequently, smoking-related mortality is higher among these populations. ${ }^{41}$ There is a strong association between smoking prevalence and socioeconomic position, which has become stronger over time. ${ }^{42}$

Table 2 outlines the prevalence of cigarette smoking for Europeans, Māori, Pacific people and Asian people. The table reports on regular smokers who are defined as someone who actively smokes one or more manufactured or hand-rolled tobacco cigarettes per day. ${ }^{43}$

Table 2. Prevalence of Cigarette Smoking ${ }^{44}$

\begin{tabular}{|l|l|l|l|l|}
\hline & $\mathbf{2 0 1 3}$ & $\mathbf{2 0 1 8}$ & Absolute Change & Relative Change \\
\hline European & $13.4 \%$ & $11.9 \%$ & $-1.5 \%$ & $-11.2 \%$ \\
\hline Māori & $30.9 \%$ & $28.3 \%$ & $-2.6 \%$ & $-8.4 \%$ \\
\hline Pacific people & $21.6 \%$ & $21.2 \%$ & $-0.4 \%$ & $-1.9 \%$ \\
\hline Asian & $7.2 \%$ & $6.8 \%$ & $-0.4 \%$ & $-5.6 \%$ \\
\hline Gap: European-Māori & $-17.5 \%$ & $-16.4 \%$ & Closing gap of 1.1\% & $-6.3 \%$ \\
\hline Gap: European-Pacific people & $-8.2 \%$ & $-9.3 \%$ & Increasing gap of 1.1\% & $+13.4 \%$ \\
\hline Gap: European-Asian & $+6.2 \%$ & $+5.1 \%$ & Closing gap of 1.1\% & $-17.7 \%$ \\
\hline
\end{tabular}

Journal of New Zealand Studies NS32 (2021), 2-39 - https://doi.org/10.26686/jnzs.iNS32.6863 
As shown in Table 2, all ethnic groups have reduced prevalence of cigarette smoking over the five-year period shown. Europeans have the largest relative change, with a reduction of 11.2 percent, and Māori experienced the second largest reduction at 8.4 percent. The Asian ethnic group started from a lower base than all other ethnic groups and reduced 5.6 percent, reflecting an absolute reduction of just 0.4 percent.

While the overall trend of declining tobacco usage is positive, the proportions of Māori and Pacific people who consume tobacco products still remain high, at 28.3 percent for Māori and 21.2 percent for Pacific people. The high levels of tobacco consumption are problematic for multiple reasons. As noted in the previous subsection, Māori and Pacific people frequently have poorer health outcomes than other ethnic groups and tobacco usage contributes to these outcomes.

In 2010, a series of excise taxes on tobacco was introduced, which rolled out over a 10-year period through to January 2020. The excise tax resulted in increasing the price of tobacco by 10 percent in addition to the annual consumer price index (CPI) based increase on the first of January of every year. An evaluation undertaken by Ernst Young in 2018, when the policy had been in place for nine years, reported that the policy had been successful in reducing smoking prevalence among some groups and in encouraging young people not to commence tobacco consumption. However, the evaluation also reports higher levels of smokers who had never tried to quit among Māori (9 percent) and Pacific ( 8 percent) populations, compared to their European (3 percent) or Asian (3 percent) counterparts. ${ }^{45} \mathrm{~A}$ further issue with the tax is that it is widely agreed to be regressive, as smoking prevalence is higher among lower socioeconomic groups. ${ }^{46}$ However, it is also argued that the tobacco tax increases can be progressive, as they result in stronger behavioural responses among the lower socioeconomic groups. ${ }^{47}$ There is also the suggestion that the higher price of tobacco is increasing crime and the use of illicit drugs instead of tobacco, although there is a paucity of appropriate data to support such suggestions. ${ }^{48}$

\section{Obesity}

Research shows that adults and children living in the most socioeconomically deprived areas are more likely to be obese than those living in the least deprived areas. ${ }^{49}$ Table 3 outlines obesity among Europeans, Māori, Pacific people and Asian people. These figures have been age standardised to control for differences in the age structures of the population.

Table 3. Proportions of People who are Overweight or Obese (Aged 15 Years and Over) ${ }^{50}$

\begin{tabular}{|l|l|l|l|l|}
\hline & $\begin{array}{l}\mathbf{2 0 1 1 -} \\
\mathbf{2 0 1 2}\end{array}$ & $\begin{array}{l}\mathbf{2 0 1 8}- \\
\mathbf{2 0 1 9}\end{array}$ & Absolute Change & Relative Change \\
\hline European & $64.7 \%$ & $65.0 \%$ & $+0.3 \%$ & $+0.5 \%$ \\
\hline Māori & $76.0 \%$ & $74.9 \%$ & $-1.1 \%$ & $-1.4 \%$ \\
\hline Pacific people & $89.1 \%$ & $87.0 \%$ & $-2.1 \%$ & $-2.4 \%$ \\
\hline Asian & $42.1 \%$ & $50.5 \%$ & $+8.4 \%$ & $+20.0 \%$ \\
\hline
\end{tabular}




\begin{tabular}{|l|l|l|l|l|}
\hline Gap: European-Māori & $-11.3 \%$ & $-9.9 \%$ & Closing gap of 1.4\% & $-12.4 \%$ \\
\hline Gap: European-Pacific people & $-24.4 \%$ & $-22.0 \%$ & Closing gap of 2.4\% & $-9.8 \%$ \\
\hline Gap: European-Asian & $+22.6 \%$ & $+14.5 \%$ & Closing gap of $8.1 \%$ & $-35.8 \%$ \\
\hline
\end{tabular}

There are large differences between the ethnic groups in the proportions of people who are overweight or obese. Unlike our previous study, the gaps in obesity between Māori and Europeans, and Pacific people and Europeans, both show decreases over the time period investigated. Notwithstanding these decreasing gaps, the gaps are still high for both these ethnic groups, with a gap of nearly 10 percentage points between European and Māori, and a gap of 22 percentage points between European and Pacific people.

While, for Māori and Pacific people, the trend is in the preferred direction, this is not the same for Asian people. Table 3 shows an 8.4 percentage point increase, or a relative 20 percent increase in the proportion of Asian population who are obese over the time period examined. Proposed reasons for this increased prevalence of obesity in Asian people living in NZ include undertaking less physical activity than Europeans, and low consumption of fruit and vegetables. $^{51}$ Despite this increase, Asian people have the lowest prevalence of being overweight or obese, both in the first and the second period. However, there may still be cause for concern that the prevalence of being overweight and obese is increasing among the Asian population. As research indicates, there exists a high risk of obesity-related diseases even at low body mass index (BMI) levels in Asian Indian and Chinese populations. ${ }^{52}$

Notwithstanding the decreasing gap between Europeans and Māori, and Europeans and Pacific people, the gaps that remain are only gradually reducing. At the current rate of decline, it will take approximately 50 and 64 years to eliminate the gap for Māori and Pacific people, respectively.

We used the normal statistic to compare binomial proportions to test for differences by year and ethnic group. Māori and Pacific people experience a statistically significant reduction in age standardised prevalence between 2011 and 2012 and between 2018 and 2019 (p<.00005), while European and Asian ethnic groups experience a statistically significant increase $(\mathrm{p}<.00005)$. In addition, each ethnic group was significantly different from the other three in both periods, 2011-2012 and 2018-2019 (p<.00005).

\section{Age-Standardised Suicide Rates}

The age-standardised suicide indicator reports on deaths by suicide per 100,000 people. Data for 2010 and 2016 are shown in Table 4. Data for 2016 was released in 2019, as a death is only officially classified as suicide on completion of a coroner's inquiry, which can take some time to complete after an unexplained death. ${ }^{53}$

Males in general, and Māori males in particular, have experienced the highest suicide rates in NZ. Figures for Pacific people are not available for this indicator. The age-standardised rate of suicide in NZ is 11.3 per 100,000 (17.0 for male suicides and 5.8 for female suicides) ${ }^{54}$

Journal of New Zealand Studies NS32 (2021), 2-39 - https://doi.org/10.26686/jnzs.iNS32.6863 
Table 4. Age-Standardised Suicide Rates for Māori and Non-Māori ${ }^{55}$

\begin{tabular}{|l|l|l|l|l|}
\hline & $\mathbf{2 0 1 0}$ & $\mathbf{2 0 1 6}$ & Absolute Change & Relative Change \\
\hline Non-Māori (male) & 16.1 & 14.3 & -1.8 & $-11.2 \%$ \\
\hline Non-Māori (female) & 5.9 & 4.9 & -1.0 & $-16.9 \%$ \\
\hline Māori (male) & 23.7 & 31.7 & +8.0 & $+33.8 \%$ \\
\hline Māori (female) & 8.7 & 10.1 & +1.4 & $+16.1 \%$ \\
\hline Gap: Non-Māori male-Māori male & -7.6 & -17.4 & Increasing gap of 9.8 & $+128.9 \%$ \\
\hline Gap: Non-Māori female-Māori female & -2.8 & -5.2 & Increasing gap of 2.4 & $+85.7 \%$ \\
\hline
\end{tabular}

The male Māori suicide rate is 23.7 and 31.7 suicides per 100,000 of population in 2010 and 2016 , respectively. This is higher than the 16.1 and 14.3 suicides per 100,000 of population in the same period for non-Māori males. The female Māori suicide rate increased from 8.7 in 2010 to 10.1 suicides per 100,000 in 2016 , following the trend we noted in our previous article. Meanwhile non-Māori female suicide rates declined from 5.9 to 4.9, reversing the trend noted in the previous study. Female suicide rates remain considerably lower than males.

The gap in suicide rates has increased between the two groups over the six-year period investigated. This also repeats the trend we reported in our previous article where the data showed an increasing gap between Māori and non-Māori suicides for both males and females. Over the period examined, the gap for males has increased by 9.8 per 100,000 of population (129 percent), while female counterparts have experienced a relatively small increase in gap, 2.4 per 100,000 of population (86 percent).

In 2019, the NZ Ministry of Health published two documents: a suicide prevention strategy for the next 10 years; and a suicide prevention action plan for the next five years. ${ }^{56}$ These documents acknowledge the high suicide rates in NZ and outline a collective approach to suicide prevention.

\section{Infant Mortality Rates}

The infant mortality indicator is measured by deaths of children under one year of age per 1,000 live births. Table 5 shows infant mortality rates among different ethnic groups in 2010 and 2018.

Table 5. Infant Mortality Rates (Per 1,000 Live Births) ${ }^{57}$

\begin{tabular}{|l|l|l|l|l|}
\hline & $\mathbf{2 0 1 0}$ & $\mathbf{2 0 1 8}$ & Absolute Change & Relative Change \\
\hline European & 3.8 & 3.1 & -0.7 & $-18.4 \%$ \\
\hline Māori & 6.6 & 4.7 & -1.9 & $-28.8 \%$ \\
\hline Pacific people & 5.8 & 4.7 & -1.1 & $-19.0 \%$ \\
\hline Asian & 3.3 & 2.5 & -0.8 & $-24.2 \%$ \\
\hline Gap: European-Māori & -2.8 & -1.6 & Closing gap of 1.2 & $-42.9 \%$ \\
\hline Gap: European-Pacific people & -2.0 & -1.6 & Closing gap of 0.4 & $-20.0 \%$ \\
\hline Gap: European-Asian & +0.5 & +0.6 & Increasing gap of 0.1 & $+20.0 \%$ \\
\hline
\end{tabular}


Infant mortality rates have declined for all ethnic groups in the time period shown. This is a general trend since 1900. ${ }^{58}$ However, the greatest improvements are in the Māori and Pacific people groups. While the rates for Māori and Pacific people in 2018 remain higher than the European and Asian, the gap is less pronounced, with both Māori and Pacific people showing relative improvements in infant mortality rates of 29 percent and 19 percent, respectively. This follows the trend reported in the prior study, where infant mortality rates declined for Māori, Pacific people, and non-Māori/non-Pacific people.

The most recent decline in infant mortality moves NZ rates closer to those reported in other OECD countries. OECD countries' infant mortality rates range between 2.5 and 5.0 deaths per 1,000 live births, with an average of 3.9. ${ }^{59}$ The average infant mortality rate in NZ is 3.9. ${ }^{60}$

\section{Knowledge and Skills}

As observed in the previous study, enhancing people's knowledge and skills provides them with greater options in life. Education is one of the most well-known keys to success. ${ }^{61}$ However, the impact of poverty-related factors-such as nutrition, stress levels, and stimulation in the home - on educational success can be significant. ${ }^{62}$

A United Nations International Children's Emergency Fund (UNICEF) publication in 2018 creates a league table of inequality in children's education in 41 developed OECD and EU countries. ${ }^{63}$ The league table reports on educational inequalities at preschool, primary and secondary school. The publication observes that in some wealthy countries, some children may have poorer outcomes where they are disadvantaged, ultimately resulting in social and economic costs. The drivers of educational inequality among children include: the national context, including economic, social and cultural factors; the educational system, including attendance at different schools; parental occupations ${ }^{64}$; and family circumstances, including parental actions. ${ }^{65}$

Of the 38 countries ranked in all three categories of the UNICEF league table, NZ is ranked thirtieth for preschool; twenty-eighth for primary school; and thirty-third for secondary school. NZ is one of three countries ranked in the bottom third for each of the three inequality in education indicators. It also performs poorly in rankings of differences in children's reading abilities at different grades. For example, NZ is ranked second-to-last of 31 countries in terms of the widest gaps in reading comprehension among students aged 10 years old (in primary school); and thirty-third of 38 countries when gaps in reading performance among secondary school students is considered (at age 15).

The following section provides data on the same four measures of knowledge and skills as the previous study: participation in early childhood education; school leavers with qualifications; the proportion of the population with a tertiary qualification; and tertiary participation rates.

Journal of New Zealand Studies NS32 (2021), 2-39 - https://doi.org/10.26686/jnzs.iNS32.6863 


\section{Participation in Early Childhood Education}

Access to high-quality early childhood education plays an important role in reducing socioeconomic inequalities that exist when children start school. ${ }^{66} \mathrm{NZ}$ 's overall participation in early childhood education is relatively low, ranking thirtieth out of 41 developed countries. ${ }^{67}$ The data in Table 6 shows participation in early childhood education across the four ethnic groups in 2012 and 2018. This measure shows how many children regularly attended early childhood education in the six months prior to starting school.

Table 6. Participation in Early Childhood Education ${ }^{68}$

\begin{tabular}{|l|l|l|l|l|}
\hline & $\mathbf{2 0 1 2}$ & $\mathbf{2 0 1 8}$ & Absolute Change & Relative Change \\
\hline European & $97.9 \%$ & $98.1 \%$ & $+0.2 \%$ & $+0.2 \%$ \\
\hline Māori & $91.1 \%$ & $95.4 \%$ & $+4.3 \%$ & $+4.7 \%$ \\
\hline Pacific people & $86.7 \%$ & $93.4 \%$ & $+6.7 \%$ & $+7.7 \%$ \\
\hline Asian & $95.7 \%$ & $98.2 \%$ & $+2.5 \%$ & $+2.6 \%$ \\
\hline Gap: European-Māori & $+6.8 \%$ & $+2.7 \%$ & Closing gap of $4.1 \%$ & $-60.3 \%$ \\
\hline Gap: European-Pacific people & $+11.2 \%$ & $+4.7 \%$ & Closing gap of $6.5 \%$ & $-58.0 \%$ \\
\hline Gap: European-Asian & $+2.2 \%$ & $-0.1 \%$ & $-2.3 \%$ (no gap) & $-104.5 \%$ \\
\hline
\end{tabular}

Table 6 shows that there have been increases in early childhood education participation for all ethnic groups. However, Europeans have experienced the lowest increase in participation rates, 0.2 percent. Note that the starting point is relatively higher for this ethnic group, 97.9 percent. The second lowest increase belongs to Asian children who have the highest participation in 2018. The changes in the six-year period for both Māori and Pacific people are evident, with an increase in Māori early childhood education participation from 91.1 percent to 95.4 percent (an increase of 4.3 percentage points or 4.7 percent) and an increase in Pacific people participation from 86.7 percent to 93.4 percent (an increase of 6.7 percentage points or 7.7 percent). While gaps in this indicator still remain, they continue to close.

\section{School Leavers with a Qualification of NCEA Level 2 or Equivalent}

Another important indicator of knowledge and skills in society is educational attainment. Table 7 shows the proportion of 18-year-olds who leave school and hold the minimum qualification of National Certificate of Educational Achievement (NCEA) Level 2 or higher. NCEA is the main secondary school qualification in NZ. ${ }^{69}$ 
Table 7. School Leavers with a Minimum of NCEA Level 2 or Above ${ }^{70}$

\begin{tabular}{|l|l|l|l|l|}
\hline & $\mathbf{2 0 1 1}$ & $\mathbf{2 0 1 8}$ & Absolute Change & Relative Change \\
\hline European & $79.3 \%$ & $88.3 \%$ & $+9.0 \%$ & $+11.3 \%$ \\
\hline Māori & $57.1 \%$ & $76.1 \%$ & $+19.0 \%$ & $+33.3 \%$ \\
\hline Pacific people & $65.5 \%$ & $79.8 \%$ & $+14.3 \%$ & $+21.8 \%$ \\
\hline Asian & $84.6 \%$ & $90.6 \%$ & $+6.0 \%$ & $+7.1 \%$ \\
\hline Gap: European-Māori & $+22.2 \%$ & $+12.2 \%$ & Closing gap of 10.0\% & $-45.0 \%$ \\
\hline Gap: European-Pacific people & $+13.8 \%$ & $+8.5 \%$ & Closing gap of 5.3\% & $-38.4 \%$ \\
\hline Gap: European-Asian & $-5.3 \%$ & $-2.3 \%$ & Closing gap of 3.0\% & $-56.6 \%$ \\
\hline
\end{tabular}

Table 7 demonstrates improvements in educational achievement among all ethnic groups. The largest improvement belongs to Māori students, with a 19 percentage point change (or 33.3 percent in relative terms) over the seven-year period shown. Pacific people also had a considerable improvement over this period, showing a 14.3 percentage point improvement (or 21.8 percent in relative terms). These figures continue the trend observed in the earlier article. The European and Asian ethnic groups show smaller improvements at 9 and 6 percentage points, respectively. However, note that these two groups start from a higher baseline.

Despite the strong increase in numbers of school leavers achieving a minimum qualification, gaps still remain, with a 12.2 percentage point gap between Europeans and Māori students, and an 8.5 percentage point gap between European and Pacific students.

\section{Proportion of the Population with a Bachelor's Degree or Higher}

Table 8 shows the proportion of the European, Māori, Pacific people and Asian people aged 15 years and over holding a bachelor's degree or above as their highest qualification.

Table 8. Proportion of the Population with a Bachelor's Degree or Above $\mathrm{e}^{71}$

\begin{tabular}{|l|l|l|l|l|}
\hline & $\mathbf{2 0 1 3}$ & $\mathbf{2 0 1 8}$ & Absolute Change & Relative Change \\
\hline European & $18.6 \%$ & $16.7 \%$ & $-1.9 \%$ & $-10.2 \%$ \\
\hline Māori & $9.1 \%$ & $9.1 \%$ & $0.0 \%$ & $0.0 \%$ \\
\hline Pacific people & $7.1 \%$ & $7.7 \%$ & $+0.6 \%$ & $+8.5 \%$ \\
\hline Asian & $31.0 \%$ & $32.0 \%$ & $+1.0 \%$ & $+3.2 \%$ \\
\hline Gap: European-Māori & $+9.5 \%$ & $+7.6 \%$ & Closing gap of $1.9 \%$ & $-20.0 \%$ \\
\hline Gap: European-Pacific people & $+11.5 \%$ & $+9.0 \%$ & Closing gap of 2.5\% & $-21.7 \%$ \\
\hline Gap: European-Asian & $-12.4 \%$ & $-15.3 \%$ & $\begin{array}{l}\text { Increasing gap of } \\
2.9 \%\end{array}$ & $+23.4 \%$ \\
\hline
\end{tabular}

As seen in Table 8, proportions of the population holding bachelor's degrees or higher have increased over the period shown for two ethnic groups, namely, Pacific people and Asian people. Note that nearly a third of the Asian population hold a bachelor's degree or higher. This is almost twice the rate of the European population (16.7 percent) and over four times the rate of Pacific people (7.7 percent). Māori have remained constant at 9.1 percent. The only 
ethnic group that experienced a decrease is Europeans. While gaps remain between Europeans and Māori, and Europeans and Pacific people, they are closing.

\section{Tertiary Participation Rates}

Individuals with lower socioeconomic backgrounds particularly benefit from tertiary education. The reason for this is that those with higher socioeconomic status also benefit from other factors, such as cultural capital and networks, that can assist them in securing future employment options. These factors are not available to people from relatively disadvantaged backgrounds. $^{72}$ Despite its obvious advantages, the tertiary education participation rate is relatively low among people from lower socioeconomic groups. ${ }^{73}$ The findings of a recent publication show that almost half of the Māori labour force are at high risk of being replaced by automation, with one-third of the working age Māori population holding no qualifications. ${ }^{74}$ However, subsequent research has found a lower risk of job loss, as Māori shift into higher skilled jobs. ${ }^{75}$

There has been a general trend for people to enrol in higher-level qualifications in recent years. ${ }^{76}$ This has resulted in decreasing enrolments in diploma and certificate courses and increasing enrolments in degree courses. This trend reflects the government strategy to encourage people to undertake higher-level, higher-value qualifications. ${ }^{77}$ Table 9 shows agestandardised tertiary participation rates. ${ }^{78}$ This measure shows the percentage of the population aged 16 to 64 years when enrolled at a tertiary education provider in a formal programme of study of more than one week's duration. ${ }^{79}$ The measure does not capture private training establishments.

Despite the move towards obtaining higher qualifications, the overall participation rate in tertiary education has shown a general decline in recent years.

Table 9. Age-Standardised Tertiary Participation Rates ${ }^{80}$

\begin{tabular}{|l|l|l|l|l|}
\hline & $\mathbf{2 0 1 2}$ & $\mathbf{2 0 1 8}$ & Absolute Change & Relative Change \\
\hline European & $8.5 \%$ & $7.4 \%$ & $-1.1 \%$ & $-12.9 \%$ \\
\hline Māori & $10.2 \%$ & $8.8 \%$ & $-1.4 \%$ & $-13.7 \%$ \\
\hline Pacific people & $8.2 \%$ & $7.3 \%$ & $-0.9 \%$ & $-11.0 \%$ \\
\hline Asian & $7.9 \%$ & $6.5 \%$ & $-1.4 \%$ & $-17.7 \%$ \\
\hline Gap: European-Māori & $-1.7 \%$ & $-1.4 \%$ & Closing gap of $0.3 \%$ & $-17.6 \%$ \\
\hline Gap: European-Pacific people & $+0.3 \%$ & $+0.1 \%$ & Closing gap of $0.2 \%$ & $-66.7 \%$ \\
\hline Gap: European-Asian & $+0.6 \%$ & $+0.9 \%$ & Increasing gap of $0.3 \%$ & $+50.0 \%$ \\
\hline
\end{tabular}

The previous article reported increasing tertiary participation rates in all ethnic groups. It also reported that the gaps in tertiary participation rates had been eliminated. Table 9 shows declines in age-standardised tertiary participation rates in all ethnic groups. Although the base year reported here is 2012, the peak for all ethnic groups was observed in $2010{ }^{81}$ Since then, there have been some small fluctuations. However, the overall trend has been a decline across all 
ethnic groups. Factors such as economic recessions and high unemployment are associated with higher participation in tertiary education. These were factors that were visible in NZ around the time that tertiary education participation peaked.

Note that the Asian group has the lowest level of tertiary participation. As suggested by the Ministry of Education, the observed decline in Asian participation rates is partly explained by the increase in the Asian population in NZ, as a result of a general increase in migration. ${ }^{82}$

Paid Work

This section examines indicators relating to work. Unemployment is associated with a range of negative factors, including decreased life satisfaction, lower well-being, loss of social status, lack of positive social connection, child poverty, mental health problems, and alcohol and drug problems. ${ }^{83}$ Low-skilled, low-income jobs have the potential to amplify these negative factors due to, among other factors, their higher exposure to economic downturn or automation. ${ }^{84}$ Lower incomes are associated with general poorer outcomes, such as poorer health, as well as specific factors such as decreasing home ownership. ${ }^{85}$ There are large gaps in average incomes for Māori and other NZ workers. At every age level, Māori people receive lower average income, estimated to total $\$ 2.6$ billion per annum. ${ }^{86}$

Data on five indicators relating to work are explained in the following sections. These include unemployment, employment, workplace injury, weekly earnings and welfare benefit receipt.

\section{Unemployment}

The first indicator of work is the quarterly unemployment rate in December 2012 and December 2018, as shown in Table 10.

Table 10. December Quarterly Unemployment ${ }^{87}$

\begin{tabular}{|l|l|l|l|l|}
\hline & $\mathbf{2 0 1 2}$ & $\mathbf{2 0 1 8}$ & Absolute Change & Relative Change \\
\hline European & $5.5 \%$ & $3.6 \%$ & $-1.9 \%$ & $-34.5 \%$ \\
\hline Māori & $14.8 \%$ & $8.2 \%$ & $-6.6 \%$ & $-44.6 \%$ \\
\hline Pacific people & $16.0 \%$ & $8.5 \%$ & $-7.5 \%$ & $-46.9 \%$ \\
\hline Asian & $8.1 \%$ & $4.3 \%$ & $-3.8 \%$ & $-46.9 \%$ \\
\hline Gap: European-Māori & $-9.3 \%$ & $-4.6 \%$ & Closing gap of 4.7\% & $-50.5 \%$ \\
\hline Gap: European-Pacific people & $-10.5 \%$ & $-4.9 \%$ & Closing gap of 5.6\% & $-53.3 \%$ \\
\hline Gap: European-Asian & $-2.6 \%$ & $-0.7 \%$ & Closing gap of $1.9 \%$ & $-73.1 \%$ \\
\hline
\end{tabular}

Table 10 shows declining unemployment for all ethnic groups over the time period examined. For Māori, Pacific people and Asian people, the unemployment rate gap with European people decreased over the period shown. Note that the higher levels of unemployment shown in the earlier time period reported in Table 10 (2012) is likely to reflect the impact of the Global Financial Crisis. 
Logistic regression shows that the unemployment rate decreased significantly from December 2012 to December 2018 ( $\mathrm{p}<.0005)$. Moreover, the unemployment rates were significantly different by ethnic groups, both in December 2012 and December $2018\left(X^{2}(2), p<.0005\right.$ in both cases).

\section{Employment}

In contrast to the unemployment rates reported in the previous table, the following table reports employment rates for those aged 15 and over. Note that employment rates capture those who work for at least one hour per week. Data for December 2012 and 2018 are shown in Table 11.

Table 11. December Quarterly Employment ${ }^{88}$

\begin{tabular}{|l|l|l|l|l|}
\hline & $\mathbf{2 0 1 2}$ & $\mathbf{2 0 1 8}$ & Absolute Change & Relative Change \\
\hline European & $65.0 \%$ & $68.5 \%$ & $+3.5 \%$ & $+5.4 \%$ \\
\hline Māori & $55.2 \%$ & $63.6 \%$ & $+8.4 \%$ & $+15.2 \%$ \\
\hline Pacific people & $50.1 \%$ & $60.3 \%$ & $+10.2 \%$ & $+20.4 \%$ \\
\hline Asian & $61.6 \%$ & $68.6 \%$ & $+7.0 \%$ & $+11.4 \%$ \\
\hline Gap: European-Māori & $+9.8 \%$ & $+4.9 \%$ & Closing gap of $4.9 \%$ & $-50.0 \%$ \\
\hline Gap: European-Pacific people & $+14.9 \%$ & $+8.2 \%$ & Closing gap of $6.7 \%$ & $-45.0 \%$ \\
\hline Gap: European-Asian & $+3.4 \%$ & $-0.1 \%$ & $3.5 \%$ (no gap) & $-102.9 \%$ \\
\hline
\end{tabular}

In contrast to the findings reported in the prior article, all ethnic groups show increases in employment over the period examined. Like unemployment figures, these represent improved economic conditions over the six-year period shown.

Both measures of paid work show all ethnic groups moving in the same direction - the reverse direction to those reported in the prior article, which was increasing levels of unemployment and decreasing levels of employment. Notwithstanding the decline in gaps observed in these two measures, Māori and Pacific people continue to be over-represented in unemployment figures and under-represented in employment figures, when compared to the European ethnic group.

Logistic regression analysis shows that the employment rates increased significantly between December 2012 and December 2018. The employment rates for both Māori and Pacific people increased significantly more than the employment rate for Europeans over this time, with a larger increase for Pacific people (20.4 percent) than for Māori (15.2 percent). Moreover, in both December 2012 and December 2018 the employment rates were significantly different by ethnic groups $\left(\mathrm{X}^{2}, \mathrm{p}<.0005\right)$.

\section{Workplace Injury}

Workplace injury rates are outlined in Table 12. This indicator reports the incidence rate, which is the number of workplace injury claims per 1,000 full-time equivalent employees. 
Table 12. Workplace Injury Claims (Per 1,000 Full-Time Equivalent Workers) ${ }^{89}$

\begin{tabular}{|l|l|l|l|l|}
\hline & $\mathbf{2 0 1 2}$ & $\mathbf{2 0 1 7}^{90}$ & Absolute Change & Relative Change \\
\hline European & 87 & 82 & -5 & $-5.7 \%$ \\
\hline Māori & 90 & 101 & +11 & $+12.2 \%$ \\
\hline Pacific people & 111 & 99 & -12 & $-10.8 \%$ \\
\hline Asian & 55 & 60 & +5 & $+9.1 \%$ \\
\hline Gap: European-Māori & -3 & -19 & Increasing gap of 16 & $+533.3 \%$ \\
\hline Gap: European-Pacific people & -24 & -17 & Closing gap of 7 & $-29.2 \%$ \\
\hline Gap: European-Asian & 32 & 22 & Closing gap of 10 & $-31.3 \%$ \\
\hline
\end{tabular}

Workplace injury claims declined for Europeans and Pacific people, which followed the trend reported in the previous study. However, workplace injury claims increased for Māori, reversing the decline trend noted previously. The patterns shown result in increased gaps between Māori and Europeans and decreased gaps between Europeans and Pacific people. We did not report on Asian workplace injury claims in the previous study but note the increase in reported injuries over the two time periods shown here.

We also acknowledge that this indicator may be vulnerable to reporting variances, whereby changes may reflect industry reporting practices, rather than increases or decreases in injuries. We also note the high proportion of Māori employed in high-risk industries. For example, 40 percent of the forestry workforce and 25 percent of the fishing workforce are Māori (although industry employment rates have not changed over the periods examined). ${ }^{91}$

For both 2012 and 2017, there was a significant difference in incidence of workplace injury claims between the four ethnic groups $\left(X^{2}\right.$ test, $\left.p<.0005\right)$. When the data from 2012 was compared with the data from 2017, again there was a significant reduction in incident rate for European and Pacific people and a significant increase for Māori and Asian (logistic regression model, $\mathrm{p}<.0005)$. However, although the gap between Māori and Europeans was greater in 2017 than in 2012 ( $\mathrm{p}<.0005)$, for Pacific people, the gap with Europeans was significantly lower in 2017 than in 2012 ( $\mathrm{p}<.0005)$.

\section{Weekly Earnings}

The median weekly earnings indicator reports on incomes received from wages and salaries. These figures are outlined in Table 13 for 2013 and 2018.

Journal of New Zealand Studies NS32 (2021), 2-39 - https://doi.org/10.26686/jnzs.iNS32.6863 
Table 13. Median Weekly Earnings ${ }^{92}$

\begin{tabular}{|l|l|l|l|l|}
\hline & $\mathbf{2 0 1 3}$ & $\mathbf{2 0 1 8}$ & Absolute Change & $\begin{array}{l}\text { Relative } \\
\text { Change }\end{array}$ \\
\hline European & $\$ 863 \pm 17.26$ & $\$ 1,025 \pm 20.50$ & $+\$ 162$ & $+18.8 \%$ \\
\hline Māori & $\$ 767 \pm 15.34$ & $\$ 900 \pm 18.00$ & $+\$ 133$ & $+17.3 \%$ \\
\hline Pacific people & $\$ 712 \pm 14.24$ & $\$ 863 \pm 17.26$ & $+\$ 151$ & $+21.2 \%$ \\
\hline Asian & $\$ 767 \pm 15.34$ & $\$ 918 \pm 18.36$ & $+\$ 151$ & $+19.7 \%$ \\
\hline Gap: European-Māori & $\$ 96$ & $\$ 125$ & Increasing gap of $\$ 29$ & $+30.2 \%$ \\
\hline Gap: European-Pacific people & $\$ 151$ & $\$ 162$ & Increasing gap of $\$ 11$ & $+7.3 \%$ \\
\hline Gap: European-Asian & $\$ 96$ & $\$ 107$ & Increasing gap of $\$ 11$ & $+11.5 \%$ \\
\hline
\end{tabular}

All groups show increased median weekly earnings over the period investigated. Europeans' and Asian peoples' median weekly earnings increase by 19 percent and 20 percent, respectively. The observed increases are 17 percent for Māori and 21 percent for Pacific people. While all ethnicities experience an increase in their median weekly earnings, the gaps in earning are also increasing. As can be seen, the increase in median weekly earnings of Pacific people is relatively large, as they start from a lower base. However, the gap continues to grow, since their earnings are still lower than their Europeans counterparts.

Māori, Pacific people, and Asian have significantly lower median weekly earnings in both 2013 and 2018 ( $\mathrm{z}$ test, $\mathrm{p}<.05$ ). In addition, for each ethnicity, the change from 2013 to 2018 is statistically significant (z test, $\mathrm{p}<.05)$.

\section{Benefit Receipt}

This subsection reports on the proportion of each ethnic group that is receiving one of the main welfare benefits, including Jobseeker Support, Sole Parent Support and Supported Living Payment. These are calculated as the proportion of the ethnic group working-age population who are in receipt of a core benefit. ${ }^{93}$ We have recalculated the data used in the previous article to incorporate a European category (in the earlier article, the non-Māori, non-Pacific category was used), due to changes in the way this data is reported. Table 14 shows the proportion of each ethnicity population who are in receipt of an income-tested benefit. We have not included the Asian ethnic group as this data is not reported separately.

Table 14. Proportion of Each Ethnic Group on Income-Tested Benefits ${ }^{94}$

\begin{tabular}{|l|l|l|l|l|}
\hline & $\mathbf{2 0 1 3}$ & $\mathbf{2 0 1 8}$ & Absolute Change & Relative Change \\
\hline European & $5.2 \%$ & $3.9 \%$ & $-1.3 \%$ & $-25.0 \%$ \\
\hline Māori & $23.4 \%$ & $20.0 \%$ & $-3.4 \%$ & $-14.5 \%$ \\
\hline Pacific people & $13.1 \%$ & $8.6 \%$ & $-4.5 \%$ & $-34.4 \%$ \\
\hline Gap: European-Māori & $-18.2 \%$ & $-16.1 \%$ & Closing gap of 2.1\% & $-11.5 \%$ \\
\hline Gap: European-Pacific people & $-7.9 \%$ & $-4.7 \%$ & Closing gap of 3.2\% & $-40.5 \%$ \\
\hline
\end{tabular}

Journal of New Zealand Studies NS32 (2021), 2-39 - https://doi.org/10.26686/jnzs.iNS32.6863 
Table 14 shows that receipt of welfare benefits has decreased for all three groups: European; Māori; and Pacific people. This reverses the trend for Māori previously reported (which was an increase in income-tested benefits), and continues the decreasing trend reported for Pacific people. The gaps between European and the two other ethnicities are also decreasing for this indicator.

\section{Economic Standard of Living}

Economic standard of living considers how people live. It includes housing and access to economic resources. Necessities - such as housing, and access to sufficient goods and services - are essential for well-being. ${ }^{95}$ This section outlines three measures related to economic standard of living: median incomes; personal income distribution; and housing affordability.

\section{Median Income}

The single most important driver in increasing inequality across OECD countries has been greater inequality in wages and salaries. ${ }^{96}$ Increasing household incomes is one mechanism to improve living standards and reduce poverty. This measure captures the changes in median weekly income over the period from 2013 to 2018. The difference between the median weekly income in Table 15 and the weekly earnings measure outlined in Table 13 is that the former incorporates income from all sources, such as dividends from shares and rent from property, as well as earnings from employment.

Table 15. Median Weekly Income ${ }^{97}$

\begin{tabular}{|l|l|l|l|l|}
\hline & $\mathbf{2 0 1 3}$ & $\mathbf{2 0 1 8}$ & Absolute Change & $\begin{array}{l}\text { Relative } \\
\text { Change }\end{array}$ \\
\hline European & $\$ 557 \pm 11.14$ & $\$ 690 \pm 13.80$ & $+\$ 133$ & $+23.9 \%$ \\
\hline Māori & $\$ 477 \pm 9.54$ & $\$ 614 \pm 12.28$ & $+\$ 137$ & $+28.7 \%$ \\
\hline Pacific people & $\$ 380 \pm 7.60$ & $\$ 588 \pm 11.76$ & $+\$ 208$ & $+54.7 \%$ \\
\hline Asian & $\$ 468 \pm 9.36$ & $\$ 660 \pm 13.20$ & $+\$ 192$ & $+41.0 \%$ \\
\hline Gap: European-Māori & $+\$ 80$ & $+\$ 76$ & Closing gap of $\$ 4$ & $-5.0 \%$ \\
\hline Gap: European-Pacific people & $+\$ 177$ & $+\$ 102$ & $\begin{array}{l}\text { Closing gap of } \\
\$ 75\end{array}$ & $-42.4 \%$ \\
\hline Gap: European-Asian & $+\$ 89$ & $+\$ 30$ & $\begin{array}{l}\text { Closing gap of } \\
\$ 59\end{array}$ & $-66.3 \%$ \\
\hline
\end{tabular}

Table 15 shows increases in median weekly income for all ethnicities, with the lowest increase visible for the European population. This contrasts with the prior study, in which the weekly income of the European population had increased by a considerably larger amount than that of their Pacific and Māori counterparts. The gaps between Europeans and the three other ethnic groups have all reduced over the five-year period shown, with the largest decrease visible between European and Pacific people, at $\$ 75$. 
The relative sampling errors for median weekly income derived from the New Zealand Income Survey are \pm 2 percent (accordingly, the standard errors are shown in the form of \pm ). Using a standard normal statistic to compare these medians we have:

$\begin{array}{lll} & \underline{2013} & \underline{2018} \\ \text { European vs Māori } & \mathrm{p}<.0001 & \mathrm{p}<.0001 \\ \text { European vs Pacific People } & \mathrm{p}<.0001 & \mathrm{p}<.0001 \\ \text { European vs Asian } & \mathrm{p}<.0001 & \mathrm{p}<.0001\end{array}$

\section{Personal Income Distribution}

In the prior article, we reported on ethnic representation in the lowest quintile of incomes as collected in the NZ Income Survey. However, data has not been collected for this survey since 2015. Therefore, we have amended the data source for both 2013 and 2018 to the Household Economic Survey dataset. This has resulted in some small changes from the previous article for the 2013 year. Table 16 shows the proportion of each ethnic group earning the lowest quintile of income (under \$10,399 in 2013 and under \$12,799 in 2018).

Table 16. Proportion of Ethnic Group Earning in Lowest Income Quintile ${ }^{98}$

\begin{tabular}{|l|l|l|l|l|}
\hline & $\mathbf{2 0 1 3}$ & $\mathbf{2 0 1 8}$ & Absolute Change & Relative Change \\
\hline European & $16.8 \%$ & $16.3 \%$ & $-0.5 \%$ & $-3.0 \%$ \\
\hline Māori & $22.5 \%$ & $23.9 \%$ & $+1.4 \%$ & $+6.2 \%$ \\
\hline Pacific people & $34.5 \%$ & $28.4 \%$ & $-6.1 \%$ & $-17.7 \%$ \\
\hline Asian & $32.8 \%$ & $26.2 \%$ & $-6.6 \%$ & $-20.1 \%$ \\
\hline Gap: European-Māori & $-5.7 \%$ & $-7.6 \%$ & $\begin{array}{l}\text { Increasing gap of } \\
1.9 \%\end{array}$ & $+33.3 \%$ \\
\hline Gap: European-Pacific people & $-17.7 \%$ & $-12.1 \%$ & Closing gap of 5.6\% & $-31.6 \%$ \\
\hline Gap: European-Asian & $-16.0 \%$ & $-9.9 \%$ & Closing gap of $6.1 \%$ & $-38.1 \%$ \\
\hline
\end{tabular}

The previous article showed increases in the proportion of European, Māori and Pacific people in the lowest quintile (it did not include the Asian ethnic group). The increasing trend is continued only for Māori, with other groups showing declines in their proportional representation in the lowest quintile group. Māori, Pacific people and Asian are all "overrepresented" in the lowest quintile, with over 20 percent of their respective ethnic group in this lowest quintile.

We observe the increasing gap between the European population and Māori between 2013 and 2018. This is a continuation of the trend since 2003 reported in the previous article. While there are large decreases for both Pacific people and Asian people, sizeable gaps remain between each of these ethnic groups and the European population.

We used the chi-square test to compare percentages between years and between ethnic groups. For all ethnic groups except Māori, the percentage in the lowest quintile significantly decreased

Journal of New Zealand Studies NS32 (2021), 2-39 - https://doi.org/10.26686/jnzs.iNS32.6863 
from 2013 to 2018 (chi-square test, p<.0001). For 2013 and 2018, all ethnic groups were significantly different from the other ethnic groups (chi-square test, $\mathrm{p}<.0001$ ).

\section{Housing Affordability}

The housing affordability indicator reports on the proportion of households where housing costs are at least 30 percent of disposable income. Disposable income is a modelled amount representing income after tax and social transfers. Data for this indicator is reported in Table 17.

According to this definition, Table 17 shows that housing costs have increased for European and Māori households. For European households, this continues the pattern observed in the prior study, but for Māori households this reverses the improving trend reported earlier. However, the data shows a reduction for Pacific households, reducing by 12.6 percentage points over the five-year period shown, continuing the previously observed pattern. This pattern indicates that either housing costs for Pacific people are reducing or incomes are increasing. Reference to Tables 13 and 15 shows that incomes are increasing for Pacific people, and to the extent that incomes are increasing faster than housing costs are increasing, this would, at least in part, explain the decrease shown in Table 17.

Table 17. Housing Affordability: Housing Costs Greater Than 30 percent of Disposable Household Income $^{99}$

\begin{tabular}{|l|l|l|l|l|}
\hline & $\mathbf{2 0 1 3}$ & $\mathbf{2 0 1 8}$ & Absolute Change & $\begin{array}{l}\text { Relative } \\
\text { Change }\end{array}$ \\
\hline $\begin{array}{l}\text { European households as a proportion of } \\
\text { European households }\end{array}$ & $25.7 \%$ & $28.4 \%$ & $+2.7 \%$ & $+10.5 \%$ \\
\hline $\begin{array}{l}\text { Māori households as a proportion of } \\
\text { Māori households }\end{array}$ & $31.7 \%$ & $32.0 \%$ & $+0.3 \%$ & $+0.9 \%$ \\
\hline $\begin{array}{l}\text { Pacific people households as a } \\
\text { proportion of Pacific households }\end{array}$ & $41.2 \%$ & $28.6 \%$ & $-12.6 \%$ & $-30.6 \%$ \\
\hline $\begin{array}{l}\text { Asian households as a proportion of } \\
\text { Asian households }\end{array}$ & N/A & $43.3 \%$ & N/A & N/A \\
\hline Gap: European-Māori & $-6.0 \%$ & $-3.6 \%$ & Closing gap of $2.4 \%$ & $-40.0 \%$ \\
\hline Gap: European-Pacific people & $-15.5 \%$ & $-0.2 \%$ & Closing gap of 15.3\% & $-98.7 \%$ \\
\hline Gap: European-Asian & N/A & $-14.9 \%$ & N/A & N/A \\
\hline
\end{tabular}

Table 17 shows a larger proportion of Asian households with high housing costs compared to the other ethnic groups. Asian households are over 11 percentage points higher in this indicator than the next group (Māori at 32 percent). Gaps between Māori and Europeans, and Pacific people and Europeans, continue the downward trend reported in the previous study.

\section{Cultural Identity}

Cultural identity refers to two complementary phenomena: an individual's sense of self; and how an individual relates to others. A strong cultural identity can contribute to overall well- 
being. ${ }^{100}$ We acknowledge that NZ is a multicultural society, and our selection of two measures (Māori indicators) is not intended to be representative of cultural identity in NZ. In this subsection we report data on Māori language speakers and those participating in Māorimedium education.

While these two indicators are important indicators in their own right, we acknowledge that they are not measurements of gaps between Māori and Pasifika, and other ethnic groups. These two indicators were included in the original Ministry of Social Development study that the original paper replicated. Therefore, we include them in this article for the purposes of completeness and to replicate the prior study as closely as we can.

\section{Māori Language Speakers}

The first indicator is the proportion of individuals who identify as Māori and speak te reo Māori. ${ }^{101}$ Table 18 shows an increase of 3.1 percentage points in this indicator or about 15 percent over the five-year period from 2013 and 2018. Our previous study reported a 3.9 percentage point decline over the 12-year period from 2001 to 2013.

Table 18. Māori Language Speakers ${ }^{102}$

\begin{tabular}{|l|l|l|l|l|}
\hline & $\mathbf{2 0 1 3}$ & $\mathbf{2 0 1 8}$ & Absolute Change & Relative Change \\
\hline $\begin{array}{l}\text { Proportion of Māori who speak Te Reo } \\
\text { Māori }\end{array}$ & $20.9 \%$ & $24.0 \%$ & $+3.1 \%$ & $+14.8 \%$ \\
\hline
\end{tabular}

Māori-Medium Education

The second indicator of cultural identity is Māori-medium education. The measure of Māorimedium education incorporates students who are taught Māori language for at least 51 percent of the time (at least 12.5 hours per week). Table 19 shows that in $2013,17,343$ students received at least 51 percent of course work as Māori-medium education. This had increased to 20,511 in 2018, an increase of 0.6 percent, from 9.9 percent to 10.5 percent.

Table 19. Māori-Medium Education Participation ${ }^{103}$

\begin{tabular}{|l|l|l|l|l|}
\hline & $\mathbf{2 0 1 3}$ & $\mathbf{2 0 1 8}$ & Absolute Change & Relative Change \\
\hline Māori-Medium Education & 17,343 & 20,511 & $+3,168$ & $+18.3 \%$ \\
\hline Māori students & 175,456 & 194,773 & 19,317 & $+11.0 \%$ \\
\hline $\begin{array}{l}\text { Proportion of Māori students in } \\
\text { Māori-Medium Education }\end{array}$ & $9.9 \%$ & $10.5 \%$ & $+0.6 \%$ & $+6.5 \%$ \\
\hline
\end{tabular}

As at 1 July 2018 there were 20,511 students enrolled in Māori-medium education. This represents 2.5 of the total school population. The majority of the 20,511 students identified as Māori, at 97.1 percent. ${ }^{104}$ There has been an increase of 3,168 students participating in Māorimedium education. However, the proportion of Māori students has increased by nearly 20,000

Journal of New Zealand Studies NS32 (2021), 2-39 - https://doi.org/10.26686/jnzs.iNS32.6863 
during the time period investigated. Thus, overall, there is only a small increase of 0.6 percentage points of Māori students participating in Māori-medium education.

\section{Discussion}

As stated earlier, the origin of the earlier study in 2015 was the 2003 Ministry of Social Development report, in which many of the indicators outlined above either showed an improvement or no clear trend. ${ }^{105}$ In the 2015 study, on the other hand, most of these indicators showed worsening outcomes for Māori and Pacific people in the form of increasing gaps (compared to their European counterparts). It was also concluded that while some of the indicators showed improving outcomes, there were often large gaps between the European population and each of the two ethnicities examined (Māori and Pacific people). Thus, the previous study reported not only that significant inequality remained in NZ, but that it was escalating, as measured by growing gaps in many inequality indicators.

Tables 20 and 21 provide summaries of the indicators in the prior article, to facilitate comparison with the indicators reported in the present article. The tables exclude Asian people, as the prior article did not include this ethnic group. Table 20 shows the direction of movement for each indicator in the 2015 article and in the current article. The key changes are shaded. The health indicators are mostly positive, showing general improvement trends for Māori and Pacific people. In the 2015 article, the obesity measure was worsening for Māori and Pacific people, but the current measure now shows this as improving. The health indicators that are not moving in a positive direction are European obesity and Māori suicide rates.

In the knowledge and skills category, most indicators continued their improving trend, with two exceptions. The proportion of the population with a bachelor's degree worsened for Europeans, and tertiary participation rates moved from improving across all three ethnic groups to worsening across all three groups. This may reflect the improved economic conditions between the two time periods. Research suggests that the net effect of the recession was an increase in tertiary education enrolments, which is likely to be visible in the results of the 2015 article. ${ }^{106}$ As economic conditions improve, we expect tertiary participation rates to reduce. The same improved economic conditions are also likely to be reflected in the changed directions of the unemployment and employment indicators, as well as the percentage of the population receiving a core benefit.

The data shows worsening numbers of workplace injury claims for Māori. In the 2015 article, we reported a drop of 49.7 percent in the number of workplace injuries for Māori, compared to the 12.2 percent increase reported in this article. As noted above, it is likely that the measure used is sensitive to industry reporting practices, which may offer some explanation for the change in direction of this indicator.

In the previous article, we reported that the proportional representation of all ethnic groups in the lowest income quintile over the ten-year period from 2003 to 2013 had been increased. This indicator has improved for Europeans and Pacific people between 2013 and 2018. However, it 
has continued to worsen for Māori, increasing from 20.2 percent in 2003 to 22.5 percent in 2013 and 23.9 percent in 2018.

The data shows mixed results on the housing affordability indicator. Europeans continue the trend to have worsening ability to afford housing, while Pacific people continue the trend to have improved ability to afford housing. As noted above, this is at least in part due to increases in Pacific peoples' incomes. Māori have changed from having an improved ability to afford housing to having a worsening ability to do so. In the prior article we also reported on a measure of household crowding. We have not been able to obtain comparable data for the current article, but we note that the measures of household crowding and household affordability are connected. Families may live together to reduce their housing costs, resulting in increased household crowding.

Table 20. Direction of Movement: Prior and Current Article ${ }^{107}$

\begin{tabular}{|c|c|c|c|c|c|c|c|}
\hline & & \multicolumn{3}{|c|}{ Prior Article (2003-2013) } & \multicolumn{3}{|c|}{ Current Article (2013-2018) } \\
\hline & Indicator & European & Māori & $\begin{array}{l}\text { Pacific } \\
\text { people }\end{array}$ & European & Māori & $\begin{array}{l}\text { Pacific } \\
\text { people }\end{array}$ \\
\hline \multirow[t]{5}{*}{ Health } & $\begin{array}{l}\text { Life expectancy at } \\
\text { birth }\end{array}$ & $\mathrm{N} / \mathrm{A}^{*}$ & Improved & N/A & $\mathrm{N} / \mathrm{A}^{*}$ & Improved & N/A \\
\hline & $\begin{array}{c}\text { Prevalence of cigarette } \\
\text { smoking }\end{array}$ & Improved & Improved & Improved & Improved & Improved & Improved \\
\hline & Obesity & Worse & Worse & Worse & Worse & Improved & Improved \\
\hline & $\begin{array}{l}\text { Age-standardised } \\
\text { suicide rates }\end{array}$ & N/A* & Mixed & N/A & N/A* & Worse & N/A \\
\hline & Infant mortality rates & Improved & Improved & Improved & Improved & Improved & Improved \\
\hline \multirow[t]{4}{*}{$\begin{array}{c}\text { Knowledge } \\
\text { and Skills }\end{array}$} & $\begin{array}{c}\text { Participation in early } \\
\text { childhood education }\end{array}$ & Improved & Improved & Improved & Improved & Improved & Improved \\
\hline & $\begin{array}{c}\text { School leavers with a } \\
\text { qualification of NCEA } \\
\text { Level } 2 \text { or higher }\end{array}$ & Improved & Improved & Improved & Improved & Improved & Improved \\
\hline & $\begin{array}{c}\text { Proportion of the } \\
\text { population with a } \\
\text { bachelor's degree or } \\
\text { higher }\end{array}$ & Improved & Improved & Improved & Worse & No change & Improved \\
\hline & $\begin{array}{c}\text { Tertiary participation } \\
\text { rates }\end{array}$ & Improved & Improved & Improved & Worse & Worse & Worse \\
\hline \multirow[t]{3}{*}{ Paid Work } & Unemployment & Worse & Worse & Worse & Improved & Improved & Improved \\
\hline & Employment & Worse & Worse & Worse & Improved & Improved & Improved \\
\hline & $\begin{array}{l}\text { Workplace injury } \\
\text { claims }\end{array}$ & Improved & Improved & Improved & Improved & Worse & Improved \\
\hline
\end{tabular}

Journal of New Zealand Studies NS32 (2021), 2-39 - https://doi.org/10.26686/jnzs.iNS32.6863 


\begin{tabular}{|c|c|c|c|c|c|c|c|}
\hline & $\begin{array}{c}\text { Median weekly } \\
\text { earnings }\end{array}$ & Improved & Improved & Improved & Improved & Improved & Improved \\
\cline { 2 - 8 } & $\begin{array}{c}\text { Percentage of the } \\
\text { population receiving a } \\
\text { core benefit }\end{array}$ & Improved & Worse & Improved & Improved & Improved & Improved \\
\hline $\begin{array}{c}\text { Economic } \\
\text { Standard } \\
\text { of Living }\end{array}$ & Median weekly income & Improved & Improved & Improved & Improved & Improved & Improved \\
\cline { 2 - 8 } & Lowest income quintile & Worse & Worse & Worse & Improved & Worse & Improved \\
\cline { 2 - 8 } & Housing affordability & Worse & Improved & Improved & Worse & Worse & Improved \\
\hline
\end{tabular}

* We report this as N/A as the comparison is not to Europeans. Instead, the reference group is non-Māori.

Table 21 shows the movement of the gap between European and Māori, and European and Pacific people, comparing the two time periods. Most of the health indicators show improvements, except for the gap in cigarette smoking between European and Pacific people. While the overall trend for cigarette smoking among Pacific people is a decline, this decline is occurring at a slower rate than Europeans. The gaps in the obesity measure for both Māori and Pacific people as compared with Europeans are now closing, in contrast to the increasing gaps reported in the prior study.

In the earlier study, we reported an increasing gap between Europeans and Pacific people in the measure of school leavers with a qualification of NCEA Level 2 or higher. This gap is now closing. Here we report the figures for the two ethnic groups, namely Māori and Pacific people, over time, to indicate the extent to which this indicator has changed. For Pacific people, the measure was 54.7 percent in 2001; it then changed to 65.5 percent in 2011; and by 2018 it became 79.8 percent. For Māori, the same indicator was 40.6 percent in 2001, 57.1 percent in 2011 , and 76.1 percent in 2018. The data shows closing gaps in the proportion of the population holding a bachelor's degree or higher, in contrast to increasing gaps reported in the previous study. In the prior study we reported no gap in tertiary participation rates. As noted above, tertiary participation is sensitive to economic conditions. However, rates of Māori tertiary participation exceed Europeans, while Pacific people are very similar to Europeans.

Reflecting the improved economic conditions, gaps in measures of unemployment and employment have reduced, as has the proportion of the population receiving a core benefit, in contrast to the increases reported in the 2015 study. However, we observe different trends in the gaps with workplace injury claims: gaps that were closing in the last study are increasing (Europeans and Māori), while gaps that were increasing are now closing (Europeans and Pacific people).

Despite the improved economic conditions, median weekly earnings (wages and salaries) now show an increased gap for both Māori and Pacific people, while median weekly income (income from all sources) is showing closing gaps. Gaps in representation in the lowest income quintile continue their increasing trend for Māori, while now showing a closing gap for Pacific people. 
Table 21. Direction of Gap: Prior and Current Articles ${ }^{108}$

\begin{tabular}{|c|c|c|c|c|c|}
\hline & & \multicolumn{2}{|c|}{ Prior Article (2003-2013) } & \multicolumn{2}{|c|}{ Current Article (2013-2018) } \\
\hline & Indicator & $\begin{array}{c}\text { Gap } \\
\begin{array}{c}\text { (European \& } \\
\text { Māori) }\end{array} \\
\end{array}$ & $\begin{array}{c}\text { Gap (European \& } \\
\text { Pacific people) }\end{array}$ & $\begin{array}{c}\text { Gap } \\
\text { (European \& } \\
\text { Māori) }\end{array}$ & $\begin{array}{c}\text { Gap (European \& } \\
\text { Pacific people) }\end{array}$ \\
\hline \multirow[t]{5}{*}{ Health } & Life expectancy at birth & N/A* & N/A & $N / A^{*}$ & N/A \\
\hline & $\begin{array}{c}\text { Prevalence of cigarette } \\
\text { smoking }\end{array}$ & Closing & Closing & Closing & Increasing \\
\hline & Obesity & Increasing & Increasing & Closing & Closing \\
\hline & $\begin{array}{c}\text { Age-standardised } \\
\text { suicide rates }\end{array}$ & N/A* & N/A & N/A* & N/A \\
\hline & Infant mortality rates & Closing & Closing & Closing & Closing \\
\hline \multirow[t]{4}{*}{$\begin{array}{c}\text { Knowledge } \\
\text { and Skills }\end{array}$} & $\begin{array}{l}\text { Participation in early } \\
\text { childhood education }\end{array}$ & Closing & Closing & Closing & Closing \\
\hline & $\begin{array}{l}\text { School leavers with a } \\
\text { qualification of NCEA } \\
\text { Level } 2 \text { or higher } \\
\end{array}$ & Closing & Increasing & Closing & Closing \\
\hline & $\begin{array}{c}\text { Proportion of the } \\
\text { population with a } \\
\text { bachelor's degree or } \\
\text { higher }\end{array}$ & Increasing & Increasing & Closing & Closing \\
\hline & $\begin{array}{c}\text { Tertiary participation } \\
\text { rates }\end{array}$ & Gap is gone & Gap is gone & Closing & Closing (Minimal gap) \\
\hline \multirow[t]{5}{*}{ Paid Work } & Unemployment & Increasing & Increasing & Closing & Closing \\
\hline & Employment & Increasing & Increasing & Closing & Closing \\
\hline & Workplace injury claims & Closing & Increasing & Increasing & Closing \\
\hline & Median weekly earnings & Same & Same & Increasing & Increasing \\
\hline & $\begin{array}{c}\text { Percentage of the } \\
\text { population receiving a } \\
\text { core benefit }\end{array}$ & Increasing & Increasing & Closing & Closing \\
\hline \multirow{3}{*}{$\begin{array}{c}\text { Economic } \\
\text { Standard } \\
\text { of Living }\end{array} \mid$} & Median weekly income & Increasing & Increasing & Closing & Closing \\
\hline & Lowest income quintile & Increasing & Increasing & Increasing & Closing \\
\hline & Housing affordability & Closing & Closing & Closing & Closing \\
\hline
\end{tabular}

* We report this as N/A as the comparison is not to Europeans. Instead, the reference group is non-Māori.

Journal of New Zealand Studies NS32 (2021), 2-39 - https://doi.org/10.26686/jnzs.iNS32.6863 
In contrast to the 2015 study, the measures in this report are more positive, with many indicators showing improvements and closing gaps. In particular:

- For Europeans, 11 of the 15 indictors measured (73 percent) show improvements and four show worsening performance (27 percent).

- For Māori, 13 of the 19 indicators measured (68 percent) show improvements, five show worsening performance (26 percent) and one shows no change. Three of the indicators show increasing gaps with Europeans: workplace injury claims; median weekly earnings; and income distribution in the lowest quintile.

- For Pacific people, 14 of the 15 indicators measured (93 percent) show improvements, and one shows worsening performance. Two of the indicators show increasing gaps with Europeans: prevalence of cigarette smoking, and median weekly earnings.

- For Asian people, 10 of the 13 indicators (69 percent) show improvements, and three show worsening performance. Three of the indicators show increasing gaps with Europeans: infant mortality rates; tertiary participation rates; and median weekly earnings. A further, fourth, indicator (proportion of the population with a bachelor's degree or higher) also shows an increased gap in comparison with the European population, but this is the result of an increase in the Asian ethnic group combined with a decrease in the European ethnic group.

Research suggests that the impact of economic downturns such as recessions may vary across demographic groups (for example, ethnic groups). ${ }^{109}$ While certain groups might be hit harder, the recovery would also be faster for these groups following the recession. Note that we do not attempt to demonstrate that this is the case in NZ; our observation of the indicator trends from the previous article to the current article is that the poorer performance reported in the last article may have incorporated some of the effects of the Global Financial Crisis. This would also support the positive results that were reported in the 2003 publication. Investigation of individual-level data is required for such indication. To examine the impact of adverse economic events on ethnic groups more closely, further research is recommended.

At the time of writing, we observe that the New Zealand economy is forecast to take a downturn as a result of the COVID-19 virus. Therefore, our expectation is that indicators for Māori and Pacific people will revert to the poorer trends that were visible in the previous article.

We also rank performance in each of the indicators. This is shown in Appendix 2. The ranking exercise shows how well the European ethnic group performs in each of these indicators compared to Māori and Pacific people. The European ethnic group is ranked first or second in all the indicators shown: ranked first in six indicators, and second in nine indicators. The Asian 
ethnic group is also ranked first or second in most indicators, but is ranked last in two indicators (tertiary participation rates and housing affordability) and third in one (lowest income quintile). By way of contrast, Māori is ranked first only once (in tertiary participation rates) and second only once (lowest income quintile). There is a similar position for Pacific people, who are not ranked first in any of the indicators and second in two.

The low Asian ranking in tertiary participation rates contrasts with the results shown in Table 8 , which outlines the proportion of the population holding a bachelor's degree or above. The Asian population has almost double the proportion of population holding a bachelor's degree as the European population. As mentioned earlier, the lower participation rate in tertiary education among Asian group is partly explained by an increase in the Asian population as a result of higher levels of migration. ${ }^{110}$

As with the previous study, we acknowledge the limitations of this research. These include the inherent difficulties in making generalisations from a selected time period. It is certainly possible for movements within the time period to be smoothed, which may limit the visibility of additional trends in the measures discussed. However, the presence of the original study allows us to track performance of indicators over time. Our approach does not follow the same individuals and/or households over time. Instead, it focuses on cross-sectional comparisons using aggregate data. While the cross-sectional comparisons may result in misleading conclusions, because they necessarily ignore the relative income mobility of individuals within the income distribution over time, the main aim of this study is to examine inequality at a specific time across different ethnic groups.

Finally, we acknowledge the importance of continuing to measure and report on the trends in the indicators shown above. There is also likely to be benefit from increasing the number and types of indicators included in the study.

\section{Conclusion}

While the outcomes in this study are generally more positive than the prior article, they remain far from ideal. Some large gaps remain, particularly for Māori and Pacific people in the areas of life expectancy, cigarette smoking, overweight and obesity, suicide, school leaver achievements, tertiary qualifications, unemployment and employment, workplace injury, earnings and welfare receipt. As we note above, many of the indicators show closing gaps, but in some cases, it is likely to take dozens and sometimes more than 100 years for the indicators to become similar across the ethnic groups if the current pace continues.

This study added the Asian ethnic group to the previous study. This has further highlighted the ethnic inequalities in New Zealand. Europeans and Asian people rank higher in most indicators than Māori and Pacific people.

We do not seek to offer solutions to the inequalities we have noted. Each indicator is underpinned by a set of complex factors that contribute to the outcomes reported. We observe 
the focus of the current government on well-being and poverty, with initiatives such as the Child Poverty Reduction Act 2018 requiring the government to set targets on a defined set of child poverty measures; the introduction of well-being budgets; and increased funding for lifting Māori and Pacific incomes, skills and opportunities.

Journal of New Zealand Studies NS32 (2021), 2-39 - https://doi.org/10.26686/jnzs.iNS32.6863 
Appendix 1. Summary of Indicators and Findings

\begin{tabular}{|c|c|c|c|c|c|c|c|c|c|}
\hline Group & Table & Indicator & European & Māori & $\begin{array}{l}\text { Pacific } \\
\text { people }\end{array}$ & Asian & $\begin{array}{c}\text { Gap (European } \\
\text { \& Māori) }\end{array}$ & $\begin{array}{c}\text { Gap } \\
\begin{array}{c}\text { European \& } \\
\text { Pacific) }\end{array} \\
\end{array}$ & $\begin{array}{c}\text { Gap (European } \\
\text { \& Asian) }\end{array}$ \\
\hline \multirow{5}{*}{ Health } & 1 & Life expectancy at birth & N/A & Improved & N/A & N/A & N/A & N/A & N/A \\
\hline & 2 & $\begin{array}{c}\text { Prevalence of cigarette } \\
\text { smoking }\end{array}$ & Improved & Improved & Improved & Improved & Closing & Increasing & Closing \\
\hline & 3 & Obesity & Worse & Improved & Improved & Worse & Closing & Closing & Closing* \\
\hline & 4 & $\begin{array}{c}\text { Age-standardised } \\
\text { suicide rates }\end{array}$ & N/A & Worse & N/A & N/A & N/A & N/A & N/A \\
\hline & 5 & Infant mortality rates & Improved & Improved & Improved & Improved & Closing & Closing & Increasing \\
\hline \multirow{4}{*}{$\mid \begin{array}{c}\text { Knowledge } \\
\text { and Skills }\end{array}$} & 6 & $\begin{array}{l}\text { Participation in early } \\
\text { childhood education }\end{array}$ & Improved & Improved & Improved & Improved & Closing & Closing & No gap \\
\hline & 7 & $\begin{array}{c}\text { School leavers with a } \\
\text { qualification of NCEA } \\
\text { Level } 2 \text { or higher }\end{array}$ & Improved & Improved & Improved & Improved & Closing & Closing & Closing \\
\hline & 8 & $\begin{array}{l}\text { Proportion of the } \\
\text { population with a } \\
\text { bachelor's degree or } \\
\text { higher }\end{array}$ & Worse & No change & Improved & Improved & Closing & Closing & Increasing $* *$ \\
\hline & 9 & $\begin{array}{l}\text { Tertiary participation } \\
\text { rates }\end{array}$ & Worse & Worse & Worse & Worse & Closing & $\begin{array}{l}\text { Closing } \\
\text { (Minimal } \\
\text { gap) }\end{array}$ & Increasing \\
\hline \multirow{2}{*}{ Paid Work } & 10 & Unemployment & Improved & Improved & Improved & Improved & Closing & Closing & Closing \\
\hline & 11 & Employment & Improved & Improved & Improved & Improved & Closing & Closing & No gap \\
\hline
\end{tabular}

Journal of New Zealand Studies NS32 (2021), 2-39 - https://doi.org/10.26686/jnzs.iNS32.6863 


\begin{tabular}{|c|c|c|c|c|c|c|c|c|c|}
\hline & 12 & Workplace injury claims & Improved & Worse & Improved & Worse & Increasing & Closing & Closing \\
\hline & 13 & Median weekly earnings & Improved & Improved & Improved & Improved & Increasing & Increasing & Increasing \\
\hline & 14 & $\begin{array}{c}\text { Percentage of the } \\
\text { population receiving a } \\
\text { core benefit }\end{array}$ & Improved & Improved & Improved & N/A & Closing & Closing & N/A \\
\hline \multirow{3}{*}{$\begin{array}{l}\text { Economic } \\
\text { Standard } \\
\text { of Living }\end{array}$} & 15 & Median weekly income & Improved & Improved & Improved & Improved & Closing & Closing & Closing \\
\hline & 16 & Lowest income quintile & Improved & Worse & Improved & Improved & Increasing & Closing & Closing \\
\hline & 17 & Housing affordability & Worse & Worse & Improved & N/A & Closing & Closing & N/A \\
\hline \multirow{2}{*}{$\begin{array}{l}\text { Cultural } \\
\text { Identity }\end{array}$} & 18 & $\begin{array}{c}\text { Māori language } \\
\text { speakers }\end{array}$ & N/A & Improved & N/A & N/A & N/A & N/A & N/A \\
\hline & 19 & $\begin{array}{l}\text { Māori medium } \\
\text { education }\end{array}$ & N/A & Improved & N/A & N/A & N/A & N/A & N/A \\
\hline
\end{tabular}

* Note that while the gap is closing, this is due to increasing obesity for Asian people, that is, it reflects a "catching up" and, as such, reflects a poorer outcome for the Asian ethnic group.

**Note that while the gap is increasing, this is due to improved outcomes for Asian people and worsening outcomes for Europeans. 
Appendix 2. Ranking of Indicators

\begin{tabular}{|c|c|c|c|c|c|c|}
\hline Group & Table & Indicator & European & Māori & Pacific people & Asian \\
\hline \multirow{5}{*}{ Health } & 1 & Life expectancy at birth & \multicolumn{4}{|c|}{ N/A } \\
\hline & 2 & Prevalence of cigarette smoking & 2 & 4 & 3 & 1 \\
\hline & 3 & Obesity & 2 & 3 & 4 & 1 \\
\hline & 4 & Age-standardised suicide rates & \multicolumn{4}{|c|}{ N/A } \\
\hline & 5 & Infant mortality rates & 2 & $3^{*}$ & $3^{*}$ & 1 \\
\hline \multirow{4}{*}{$\begin{array}{l}\text { Knowledge } \\
\text { and Skills }\end{array}$} & 6 & $\begin{array}{l}\text { Participation in early childhood } \\
\text { education }\end{array}$ & 2 & 3 & 4 & 1 \\
\hline & 7 & $\begin{array}{l}\text { School leavers with a qualification } \\
\text { of NCEA Level } 2 \text { or higher }\end{array}$ & 2 & 4 & 3 & 1 \\
\hline & 8 & $\begin{array}{l}\text { Proportion of the population with } \\
\text { a bachelor's degree or higher }\end{array}$ & 2 & 3 & 4 & 1 \\
\hline & 9 & Tertiary participation rates & 2 & 1 & 3 & 4 \\
\hline \multirow{5}{*}{ Paid Work } & 10 & Unemployment & 1 & 3 & 4 & 2 \\
\hline & 11 & Employment & 2 & 3 & 4 & 1 \\
\hline & 12 & Workplace injury claims & 2 & 4 & 3 & 1 \\
\hline & 13 & Median weekly earnings & 1 & 3 & 4 & 2 \\
\hline & 14 & $\begin{array}{l}\text { Percentage of the population } \\
\text { receiving a core benefit }\end{array}$ & 1 & 3 & 2 & N/A \\
\hline \multirow{3}{*}{$\begin{array}{l}\text { Economic } \\
\text { Standard of } \\
\text { Living }\end{array}$} & 15 & Median weekly income & 1 & 3 & 4 & 2 \\
\hline & 16 & Lowest income quintile & 1 & 2 & 4 & 3 \\
\hline & 17 & Housing affordability & 1 & 3 & 2 & 4 \\
\hline
\end{tabular}

* refers to the same ranking.

Journal of New Zealand Studies NS32 (2021), 2-39 - https://doi.org/10.26686/jnzs.iNS32.6863 
${ }^{1}$ See for instance Ken Mayhew and Samuel Wills, "Inequality: An Assessment," Oxford Review of Economic Policy 35, no. 3 (2019): 351.

${ }^{2}$ Lisa Marriott and Dalice Sim, "Indicators of Inequality for Māori and Pacific People," New Zealand Studies 20 (2015): 24.

${ }^{3}$ Statistics New Zealand, "Customer Update on Data Quality of 2018 Census," https://www.stats.govt.nz/news/customer-update-on-data-quality-of-2018-census.

${ }^{4}$ As people can identify with more than one ethnicity, these figures do not sum to 100 percent. This information is derived from Statistics New Zealand, "2018 Census Population and Dwelling Counts, Census Usually Resident Population Count by Ethnic Group (Grouped Total Responses),"

https://www.stats.govt.nz/information-releases/2018-census-population-and-dwelling-counts.

${ }^{5}$ Ministry of Social Development, Social Indicators for the Pacific and Maori Populations

(Wellington: Ministry of Social Development, 2003); Ministry of Social Development, Attachment 1:

Reducing Inequalities Indicators for Maori and Pacific Peoples (Wellington: Ministry of Social

Development, 2004).

${ }^{6}$ Marriott and Sim, "Indicators of Inequality."

${ }^{7}$ Richard Wilkinson and Kate Pickett, The Spirit Level: Why Equality Is Better for Everyone (London, Penguin Group, 2009).

${ }^{8}$ Joseph E. Stiglitz, The Great Divide (London: Penguin/Random House, 2015).

${ }^{9}$ Wilkinson and Pickett, The Spirit Level, 103.

${ }^{10}$ We note the argument that some inequality is desirable to generate incentives in a free market economy.

${ }^{11}$ Statistics New Zealand, "Household Economic Survey, Year Ended June 2018,"

https://www.stats.govt.nz/information-releases/household-net-worth-statistics-year-ended-june-2018.

${ }^{12}$ Thomas Piketty, Capital in the Twenty-First Century (Cambridge, MA: Belknap Press, 2014).

${ }^{13}$ Statistics New Zealand, "Household Net Worth Statistics: Year Ended June 2018,"

https://www.stats.govt.nz/information-releases/household-net-worth-statistics-year-ended-june-2018.

${ }^{14}$ Statistics New Zealand, "Wealth of Top 20 Percent Rises by $\$ 394,000, "$

https://www.stats.govt.nz/news/wealth-of-top-20-percent-rises-by-394000.

${ }^{15}$ Oxfam New Zealand, "NZ's Two Richest Men Gain \$1.1B While Poorest Kiwis Lost Out,"

https://www.oxfam.org.nz/news-media/media-releases/nzs-two-richest-men-gain-1-1b-while-poorestkiwis-lose-out/.

${ }^{16}$ Greg Ninness, "Statistics NZ Estimates the Number of Households Renting Their Homes Increased by 15,400 in the Year to June, While Owner-Occupied Houses Increased by 7900,"

https://www.interest.co.nz/property/100565/statistics-nz-estimates-number-households-renting-theirhomes-increased-15400-year.

${ }^{17}$ Statistics New Zealand, "Wealth of Top 20 Percent."

${ }^{18}$ Oxfam New Zealand, "NZ's Two Richest Men."

${ }^{19}$ Marriott and Sim, "Indictors of Inequality."

${ }^{20}$ Organisation for Economic Cooperation and Development, In It Together: Why Less Inequality

Benefits All (Paris: OECD, 2015).

${ }^{21}$ Jonathan Boston and Max Rashbrooke, Preface, in Inequality: A New Zealand Crisis, ed. J. Boston and M. Rasbhrooke (Wellington: Bridget Williams Books, 2013).

Journal of New Zealand Studies NS32 (2021), 2-39 - https://doi.org/10.26686/jnzs.iNS32.6863 
${ }^{22}$ Organisation for Economic Cooperation and Development, "Inequality and Income,"

http://www.oecd.org/social/inequality.htm.

${ }^{23}$ Boston and Rashbrooke, "Preface."

${ }^{24}$ Boston and Rashbrooke, "Preface."

${ }^{25}$ Piketty, Capital in the Twenty-First Century, 27.

${ }^{26}$ Data collected by other government departments including the Ministries of Health, Education and Social Development is also used, as is non-census data collected from Statistics New Zealand. We explain the source of the data for each dataset used in the article.

${ }^{27}$ Statistics New Zealand, "Ethnicity," https://www.stats.govt.nz/topics/ethnicity.

${ }^{28}$ Statistics New Zealand, "Ethnicity."

${ }^{29}$ Statistics New Zealand, "2018 Census Population and Dwelling Counts," Table 7.

${ }^{30}$ For some indicators, a non-Māori, non-Pacific comparison group, or a non-Māori comparison group, is used.

${ }^{31}$ John Creedy and Norman Gemmell, "Income Inequality in New Zealand: Why Conventional Estimates Are Misleading," https://www.victoria.ac.nz/_data/assets/pdf_file/0012/1673787/WP11Income-Inequality-in-NZ.pdf.

${ }^{32}$ Robin Haynes, Jamie Pearce, and Ross Barnett, "Cancer Survival in New Zealand: Ethnic, Social and Geographical Inequalities" Social Science and Medicine 67 (2008): 928.

${ }^{33}$ C. Mills, P. Reid, and R. Vaithianathan, "The Cost of Child Health Inequalities in Aotearoa New Zealand: A Preliminary Scoping Study," BMC Public Health 12 (2012): 384.

${ }^{34}$ Mills, Reid, and Vaithianathan, "The Cost of Child Health Inequalities."

${ }^{35}$ N. Wilson, T. Blakely, and M. Tobias, "What Potential Has Tobacco Control for Reducing Health Inequalities? The New Zealand Situation," International Journal for Equity in Health 5 (2006): 14.

${ }^{36}$ R. Harris et al., "Effects of Self-Reported Racial Discrimination and Deprivation on Māori Health and Inequalities in New Zealand: Cross-Sectional Study," The Lancet, 367 (2006): 9527.

${ }^{37}$ Martin Tobias et al., "Changing Trends in Indigenous Inequalities in Mortality: Lessons from New Zealand," International Journal of Epidemiology 38 (2009): 1711.

${ }^{38}$ M. Tobias and J. Cheung, "Monitoring Health Inequalities: Life Expectancy and Small Area Deprivation in New Zealand." Population Health Metrics 1 (2003): 2.

${ }^{39}$ Statistics New Zealand, "Life Expectancy," http://archive.stats.govt.nz/browse_for_stats/health/life_expectancy.aspx.

${ }^{40}$ Statistics New Zealand, "Life Expectancy." Life expectancy data is based on registered deaths in the period reported.

${ }^{41}$ Wilson, Blakely, and Tobias, "What Potential Has Tobacco Control."

${ }^{42}$ B. Borman, N. Wilson and C. Mailing, "Socio-Demographic Characteristics of New Zealand Smokers: Results from the 1996 Census," New Zealand Medical Journal 112 (1999): 460.

${ }^{43}$ Statistics New Zealand, "Census Information by Variable,"

http://archive.stats.govt.nz/Census/2013-census/info-about-2013-census-data/information-byvariable/cigarette-smoking-behaviour.aspx.

${ }^{44}$ Statistics New Zealand, "2013 Census of Population and Dwellings," http://www.stats.govt.nz; Statistics New Zealand, custom dataset, 13 December 2019.

Journal of New Zealand Studies NS32 (2021), 2-39 - https://doi.org/10.26686/jnzs.iNS32.6863 
${ }^{45}$ Ernst Young, "Ministry of Health: Evaluation of the Tobacco Excise Increases as a Contributor to Smokefree 2025, Final Report", https://www.health.govt.nz/system/files/documents/pages/evaluationtobacco-excise-increases-final-27-nov2018.pdf.

${ }^{46}$ Ernst Young, "Ministry of Health: Evaluation."

${ }^{47}$ Ernst Young, "Ministry of Health: Evaluation."

${ }^{48}$ Ernst Young, "Ministry of Health: Evaluation."

${ }^{49}$ Ministry of Health, New Zealand Health Survey 2018/19 (Wellington: Ministry of Health, 2019).

${ }^{50}$ Ministry of Health, New Zealand Health Survey 2018/19.

${ }^{51}$ Heart Foundation, "Asian Health in NZ: A Worrying Picture,"

https://www.heartfoundation.org.nz/about-us/news/blogs/asian-health-in-nz-a-worrying-picture.

${ }^{52}$ Ji Y. J. Wen, Elaine C. Rush, and Lindsay D. Plank, "Assessment of Obesity in New Zealand

Chinese: A Comparative Analysis of Adults Aged 30-39 Years from Five Ethnic Groups," New

Zealand Medical Journal 123 (2010): 1.

${ }^{53}$ Coroners are qualified lawyers appointed as judicial officers to investigate certain types of unexplained deaths.

${ }^{54}$ Ministry of Health, "Suicide Facts: 2016 Data (Provisional),"

https://www.health.govt.nz/publication/suicide-facts-2016-data-provisional.

${ }^{55}$ Ministry of Health, "Suicide Facts."

${ }^{56}$ Ministry of Health, "Every Life Matters: He Tapu te Oranga o Ia Tangata. Suicide Prevention Atrategy 2019-2029 and Suicide Prevention Action Plan 2019-2024 for Aotearoa New Zealand," https://www.health.govt.nz/system/files/documents/publications/suicide-prevention-strategy-20192029-and-plan-2019-2024-v2.pdf.

${ }^{57}$ Statistics New Zealand, custom dataset, 11 November 2019. We use a custom dataset for both years for this indicator. This is different from the original source data used in the original article.

${ }^{58}$ Statistics New Zealand, "Infant Mortality Rate Declines," https://www.stats.govt.nz/news/infantmortality-rate-declines.

${ }^{59}$ Statistics New Zealand, "Infant Mortality Rate Declines."

${ }^{60}$ Statistics New Zealand, custom dataset, 11 November 2019.

${ }^{61}$ Joseph E. Stiglitz, The Price of Inequality (London: WW Norton, 2013).

${ }^{62}$ Laura Walters, "NZ's Unequal Education System,"

https://www.newsroom.co.nz/2018/10/30/298677/nzs-unequal-education-system\#.

${ }^{63}$ UNICEF Office of Research, An Unfair Start: Inequality in Children's Education in Rich

Countries, Innocenti Report Card 15 (Florence: UNICEF Office of Research, 2018).

${ }^{64}$ UNICEF Office of Research, An Unfair Start. Children with parents in high-status jobs are more

likely to continue into higher education than children with parents in low-status jobs.

${ }^{65}$ UNICEF Office of Research, An Unfair Start. Children who are first generation immigrants do less

well at school than non-migrant children.

${ }^{66}$ UNICEF Office of Research, An Unfair Start.

${ }^{67}$ UNICEF Office of Research, An Unfair Start. Thirteen of the 41 countries had between 99 and 100 percent participation in early childhood education.

${ }^{68}$ Ministry of Education, "Prior Participation in Early Childhood Education," https://www.educationcounts.govt.nz/statistics/early-childhood-education/participation. Data as at 30 June in each year.

Journal of New Zealand Studies NS32 (2021), 2-39 - https://doi.org/10.26686/jnzs.iNS32.6863 
${ }^{69}$ The measure reports on the number of 18 -year-olds who have attained a qualification at Level 2 or above by the age of 18 .

${ }^{70}$ Education Counts, "School Leavers with NCEA Level 2 or Above,"

https://www.educationcounts.govt.nz/statistics/indicators/main/education-and-learningoutcomes/school_leavers_with_ncea_level_2_or_above.

${ }^{71}$ Statistics New Zealand, custom dataset, 10 January 2020 (for 2018 data). Statistics New Zealand, "2013 Census of Population and Dwellings" for 2013 data.

${ }^{72}$ Quacquarelli Symonds (QS), "Does Higher Education Reinforce Inequality," accessed 4 January 2020, https://www.qs.com/does-higher-education-reinforce-inequality/.

${ }^{73}$ QS, "Does Higher Education Reinforce Inequality."

${ }^{74}$ Business and Economic Research, "Change Agenda: Income Equity for Māori,"

http://www.maorifutures.co.nz/wp-content/uploads/2019/11/Income-Equity-for-Maori.pdf.

${ }^{75}$ Tokona Te Raki Māori Futures Collective et al., "Towards Futures That Work: How Māori Can

Lead Aotearoa Forward," http://www.maorifutures.co.nz/wp-content/uploads/2020/07/Tokona-Te-

Raki-Whano-2020.pdf.

${ }^{76}$ Ministry of Education, "Participation Rates in Tertiary Education,"

https://www.educationcounts.govt.nz/statistics/indicators/main/student-engagement-

participation/participation_rates_in_tertiary_education.

${ }^{77}$ Ministry of Education, "Participation Rates in Tertiary Education."

${ }^{78}$ Age standardisation removes the effect of different age distributions within different ethnic groups.

${ }^{79}$ Ministry of Education, "Participation Rates in Tertiary Education." Data relates only to domestic students.

${ }^{80}$ Ministry of Education, "Tertiary Participation Rates," https://www.educationcounts.govt.nz. We include individuals participating in level four certificates (e.g., trade qualifications); diplomas; bachelors; and other post-graduate qualifications (such as master's degrees and doctorates) in the measure. The total participation rate is the percentage of the population aged 15 years and over who were enrolled at any time during the year. Data is from students enrolled with a tertiary education provider in formal qualifications of more than 0.03 full-time equivalent (i.e., more than one week's full-time duration).

${ }^{81}$ Ministry of Education, "Participation Rates in Tertiary Education."

${ }^{82}$ Ministry of Education, "Participation Rates in Tertiary Education."

${ }^{83}$ Simon Chapple, "Why Reducing Unemployment Should Have Been a Focus for NZ's Well-Being Budget," https://theconversation.com/why-reducing-unemployment-should-have-been-a-focus-fornzs-well-being-budget-118061.

${ }^{84}$ Tokona Te Raki Māori Futures Collective et al., "Towards Futures That Work."

${ }^{85}$ Business and Economic Research, "Change Agenda."

${ }^{86}$ Business and Economic Research, "Change Agenda."

${ }^{87}$ Statistics New Zealand, "Household Labour Force Survey, December 2018 Quarter and December 2012 Quarter," https://www.stats.govt.nz/information-releases/labour-market-statistics-december2018-quarter.

${ }^{88}$ Statistics New Zealand, "Household Labour Force Survey."

${ }^{89}$ Statistics New Zealand, "Injury Statistics-Work-Related Claims: 2018," https://www.stats.govt.nz/information-releases/injury-statistics-work-related-claims-2018.

Journal of New Zealand Studies NS32 (2021), 2-39 - https://doi.org/10.26686/jnzs.iNS32.6863 
${ }^{90}$ Data is for the 2017 year, as the 2018 statistics are provisional at the time of writing.

${ }^{91}$ Tokona Te Raki Māori Futures Collective et al., "Towards Futures That Work."

${ }^{92}$ Statistics New Zealand, "Labour Market Statistics (Income): June 2018 Quarter,"

https://www.stats.govt.nz/information-releases/labour-market-statistics-income-june-2018-quarter.

Standard errors quoted as +/- 2 percent, as per the approach adopted by Statistics New Zealand.

${ }^{93}$ Data compiled from the Household Labour Force Survey.

${ }^{94}$ Calculated using the proportion of the working-age ethnic group population from the Household Labour Force Survey and data from the Ministry of Social Development. Statistics New Zealand, "Household Labour Force Survey Estimated Working-Age Population: June 2018 Quarter," and Ministry of Social Development, "2018 Benefit Fact Sheet Archive"; see national level data tables, March 2018.

${ }^{95}$ Ministry of Social Development, "The Social Report 2016-Te Pūrongo Oranga Tangata," http://socialreport.msd.govt.nz/economic-standard-of-living.html.

${ }^{96}$ Organisation for Economic Cooperation and Development, Divided We Stand: Why Inequality Keeps Rising (OECD: Paris, 2011), 17.

${ }^{97}$ Statistics New Zealand, "Labour Market Statistics," https://www.stats.govt.nz/topics/labour-market. Data shown in this table is from a different source from that used in our original article. This is because the New Zealand Income Survey, which was the source used in the original article, was discontinued in 2015 and is now published under Labour Market Statistics.

${ }^{98}$ Statistics New Zealand, "Household Economic Survey 2013," and "Household Economic Survey 2018." In 2013, the lowest quintile, quintile one, is $\$ 0-\$ 10,399$ and quintile five is $\$ 63,600$ and above. In 2018, quintile one is $\$ 0-\$ 12,799$ and quintile five is $\$ 70,000$ and above.

${ }^{99}$ Statistics New Zealand, custom dataset, 16 June 2014 and 27 November 2019.

${ }^{100}$ Ministry of Social Development, "The Social Report 2016."

${ }^{101}$ Te Reo Māori is the indigenous language of Aotearoa New Zealand. It is one of three official languages of the country.

${ }^{102}$ Statistics New Zealand, "2018 Census Population and Dwelling Counts," and "2013 Census

Population and Dwelling Counts." Calculated as (2018) the number of Māori language speakers $(185,955)$ divided by the census usually resident Māori population count $(775,836)$.

${ }^{103}$ Education New Zealand, "Māori Language in Schooling," https://www.educationcounts.govt.nz/statistics/6040, see pivot table "Student Numbers 2000-2020." Figures reported are based on the headcount of students enrolled in the school as at 1 July in the year shown.

${ }^{104}$ Ministry of Education, "Māori Language in Education,"

https://www.educationcounts.govt.nz/statistics/schooling/student-numbers/6040.

${ }^{105}$ Marriott and Sim, "Indicators of Inequality."

${ }^{106}$ Jeffrey R. Brown and Caroline M. Hoxby, How the Financial Crisis and Great Recession Affected Higher Education (Chicago: University of Chicago Press, 2014).

${ }^{107}$ Note that some of the indicators use different years, where data is not available for 2003, 2013 or 2018.

${ }^{108}$ Note that some of the indicators use different years, where data is not available for 2003, 2013 or 2018.

${ }^{109}$ Hilary Hoynes, Douglas L. Miller and Jessamyn Schaller, "Who Suffers during Recessions?"

Journal of Economic Perspectives 26 (2012): 27.

${ }^{110}$ Ministry of Education, "Participation Rates in Tertiary Education."

Journal of New Zealand Studies NS32 (2021), 2-39 - https://doi.org/10.26686/jnzs.iNS32.6863 